\title{
PERFIL DE LOS VIOLADORES SERIALES: UN ANÁLISIS DE CASOS
}

\author{
Alberto Pintado Alcázar \\ Profesor asociado de Derecho Penal y Criminología \\ de la Universidad de Murcia
}

\begin{abstract}
Sumario: 1. Fijación de la cuestión. 2. La delincuencia sexual en españa. 3. Agresiones sexuales: especial consideración hacia las violaciones. 4. Análisis jurídico-criminológico: creación de un perfil. 4.1. Víctimas de las violaciones. 4.2. Características del delincuente. 4.2.1. Circunstancias personales. 4.2.2. Contextos delictivos. 4.3. Creación de un perfil criminológico. 5. Conclusiones. 6. Bibliografía.
\end{abstract}

Resumen: La presente investigación comprende un estudio empírico sobre los violadores seriales, en el que se tiene en cuenta el análisis de diversos sucesos ocurridos en España, a partir de diferentes sentencias judiciales. El objetivo de este trabajo radica en la creación de un perfil criminal, comparando diferentes variables que nos permiten obtener características comunes a esta tipología delictiva.

Palabras clave: violadores seriales; delincuencia sexual; perfil criminal; tipología delictiva; criminología.

Abstract: The present research includes an empirical study of serial rapists, taking in to account the analysis of several events that occurred in Spain, based on judicial sentences. This work goals to create a criminal profile, comparing different variables allowing us to obtain characteristics, wich are common to this criminal typology.

Keywords: serial rapists; sexual delinquency; criminal profile; criminal typology; criminology.

\section{Fijación de la cuestión}

Cuando los medios de comunicación sacan a la luz noticias referentes a posibles sucesos relacionados con el delito de agresión sexual, se 
genera una gran alarma social que provoca que el supuesto responsable del mismo quede estigmatizado durante su ciclo vital como un agresor encuadrado dentro de dicha tipología delictiva, infracción penal que se configura como una de las más repudiadas por parte de la sociedad.

En consecuencia, en atención a la comisión de este tipo de acciones delictivas por parte de los sujetos infractores, Wikström, a través de la teoría de la acción situacional, asevera que «las personas hacen lo que hacen debido a quienes son y a las características del ambiente en el que intervienen. La clase de personas que son y la clase de contexto explica qué clase de acciones es probable que tengan lugar» ${ }^{1}$. Como se puede apreciar en dicha afirmación, este autor achaca tales comportamientos criminales al contexto social en el que el agresor se ha desarrollado vitalmente.

La comisión de este tipo de acciones delictivas podría estar relacionada directamente con la ausencia de autocontrol, acontecimiento que provoca que, ante determinados contextos, estos individuos actúen de forma punible, no llegando a reflexionar sobre las posibles consecuencias de sus acciones. Así, Serrano Maíllo afirma que «el delito tiende a producirse en sujetos con un autocontrol bajo» ${ }^{2}$.

La repetición de acciones relacionadas con estos delitos provoca que dichas acciones sean comentadas a diario en los diferentes medios de comunicación, acontecimiento que provoca un sentimiento de impotencia y odio en la colectividad. Esto no quiere decir que ahora se cometan más delitos contra la libertad sexual que antes, pero lo que sí es cierto es que actualmente tienen más repercusión.

En este sentido, en determinadas ocasiones los medios de comunicación publican informaciones irreales y fragmentarias que no hacen otra cosa que alterar la opinión pública. Así, dichos mecanismos pueden ser vistos como herramientas para generar sentimientos de cólera en los ciudadanos, los cuales pueden propagar una sensación de miedo ante tales acontecimientos ${ }^{3}$.

Redondo Illescas y Andrés Pueyo consideran que estos delitos generan una gran intranquilidad entre los ciudadanos, por lo que estiman que estas infracciones son idóneas para llevar a cabo un número amplio de investigaciones, siendo estos delincuentes unos sujetos aptos para intentar desarrollar una intervención psicológica sobre ellos ${ }^{4}$.

1 Wikström, P.H., "Por qué se delinque: Una teoría de la acción situacional», en Revista de derecho penal y criminología, vol.17, 2017, págs. 337-367.

2 Serrano Má́llo, A., El problema de las contingencias en la teoría del autocontrol. Un test de la teoría general del delito, Madrid, 2013, pág. 111.

3 Garapon, A., Juez y Democracia, Barcelona, 1997, pág. 94.

4 Redondo Illescas, S., y Andrés Pueyo, A., "La psicología de la delincuencia», en Papeles del psicólogo, vol. 28, 2007, págs. 147-156. 
Por su parte, Redondo Illescas y Garrido Genovés, en referencia a la necesidad de llevar a cabo estudios sobre la delincuencia sexual, establecen que estos delitos «constituyen, en términos cuantitativos, una mínima parte del conjunto de la delincuencia oficial de un país. Pese a su reducida frecuencia oficial, se estima que existe una mayor proporción de delincuencia sexual oculta. Además, los delitos sexuales graves, como las violaciones y los abusos sexuales a menores, pueden producir graves daños a las víctimas (especialmente, mujeres, niñas y niños), de ahí que susciten tanta alarma pública ${ }^{5}$.

Así, el Código Penal regula en el Título VIII los delitos contra la libertad e indemnidad sexual, centrándose el Capítulo I, donde vienen recogidos los artículos 178 (tipo básico), 179 (tipo cualificado de violación -acceso carnal o introducción de miembros corporales u objetos-) y 180 (agravaciones específicas para sendos artículos), exclusivamente en lo referente a las agresiones sexuales. No obstante, debido a la gravedad e importancia que generan estos delitos, el legislador considera imprescindible establecer un capítulo diferente dedicado a los abusos y agresiones sexuales cometidos sobre menores de dieciséis años, aumentando, tras la reforma del Código Penal de 2015, la edad mínima de consentimiento sexual que antes estaba fijada en los trece años.

En consecuencia, la propia determinación del título descrito presenta una clara distinción entre dos contextos delictivos claramente diferenciados, los cuales se complementan gracias a su contenido sexual. Así, dicha dualidad está formada por: i) libertad sexual y, por otro lado, ii) indemnidad sexual. En este sentido, la principal diferencia existente entre ambos tendrá su origen en la edad de la víctima, ya que los mayores de edad se configuran dentro del primer bloque, mientras que los menores o incapaces se englobarían en el segundo, ya que se entiende que aún no han desarrollado la personalidad sexual.

Asimismo, resulta fundamental pasar a desarrollar el contenido íntegro de cada uno de los artículos para proceder a su correspondiente análisis. En este sentido, el artículo 178 del Código Penal establece que se considera sujeto activo de un delito de agresión sexual a aquel sujeto que atente contra la libertad sexual de otra persona, utilizando para lograr su propósito la violencia o intimidación. Por otro lado, el artículo 179 hace referencia al acceso carnal por vía vaginal, anal o bucal; así como a la introducción de miembros corporales u objetos por alguna de las dos primeras vías, siendo condenado el autor del mismo como responsable de un delito de violación. Finalmente, el artículo 180 agrava la pena impuesta a los delincuentes que hayan cometido alguno de los

5 Redondo Illescas, S., y Garrido Genovés, V., Principios de criminología, Valencia, 2013, pág. 689. 
delitos señalados anteriormente siempre que se cumplan algunos de los siguientes requisitos:

- Trato degradante o vejatorio.

- Acciones cometidas de forma conjunta por dos o más personas.

- Víctima especialmente vulnerable, por razón de edad, enfermedad, discapacidad o situación.

- Aprovechamiento por razón de superioridad o parentesco.

- El reo haga uso de armas u otros medios igualmente peligrosos, los cuales puedan llegar a producir la muerte o lesiones de cierta gravedad en la víctima.

Analizando la redacción de dichos artículos, podría surgir cierta incertidumbre a la hora de determinar quiénes se consideran sujetos activos y pasivos de los mismos, revistiendo especial importancia el hecho de determinar en qué situaciones podría ser considerada una mujer la responsable de un delito de violación.

En este sentido, Lamarca Pérez establece una doble hipótesis relacionada con los posibles supuestos en los que los responsables de estos delitos no sean varones: i) acto cometido por una mujer sobre un hombre; ii) las relaciones homosexuales femeninas. Así, en la primera hipótesis, Lamarca Pérez establece que «también forma parte de la conducta típica el hecho de obligar al sujeto activo para conseguir una penetración vaginal, anal o bucal [...], en los casos de violencia con sujeto pasivo previamente inmovilizado o si media intimidación». Posteriormente, para hacer referencia al segundo supuesto, afirma que en este tipo de relaciones también podrían darse estos delitos a través de la introducción de miembros corporales u objetos. Finalmente, en referencia a las posibles víctimas de estos agresiones, afirma que «no existe ningún obstáculo para que puedan serlo tanto hombres como mujeres [...], con independencia incluso de que ejerza la prostitución o se halle efectivamente vinculado al sujeto activo» ${ }^{6}$.

Morales Prats y García Albero, en un intento por definir las pautas definitorias del tipo básico y agravado de los delitos contra la libertad e indemnidad sexual, afirman que cualquier persona puede llegar a convertirse en sujeto activo o pasivo de un delito de esta naturaleza, ya que, como estos investigadores establecen, «cualquiera puede atentar contra la libertad sexual» ${ }^{7}$.

6 Lamarca PÉrez, C., «Delitos contra la libertad e indemnidad sexuales», en Lamarca Pérez (Coord.), Delitos. La parte especia del Derecho Penal, Madrid, 2018, pág. 173.

7 Morales Prats, F., y García Albero, R., "De las agresiones sexuales», en Quintero Olivares (Dir.), Comentarios al Código Penal Español, Pamplona, 2016, pág. 1280. 
En este sentido, Sáinz-Cantero Caparrós, al hacer referencia a las posibles infractores que han cometido un delito de violación, establece que «la interpretación tradicional del concepto implica necesariamente la intervención de un sujeto de sexo masculino, si bien no necesariamente como sujeto activo» ${ }^{8}$. Así, dicho autor afirma que para ser considerado como responsable de este delito se podría tener en cuenta la conducta relacionada con el "acceder», la cual sólo podría ser realizada por un hombre; así como la de "hacerse acceder», acción que puede ser ejecutada por una mujer ${ }^{9}$.

Al hilo de la reforma de dicho Código, Morillas Fernández afirma que la misma podría tener su punto de partida en dos premisas primordiales, las cuales han incidido de forma directa en dicho proceso. Así, por un lado, manifiesta que era necesario trasladar a nuestro texto legal los diferentes acuerdos internacionales sobre dicha materia; por otro lado, la constante demanda por parte de los medios de comunicación y, por ende, de la sociedad en su conjunto, de modificar el Código Penal en todo lo referente a los delitos contra la libertad sexual ${ }^{10}$.

Atendiendo a la gravedad de los hechos ocasionados, Muñoz Conde considera preciso destacar que estos delitos deben identificarse con la concurrencia de una serie de acciones que lleven aparejadas una innegable entidad y trascendencia, sin olvidar el contexto social en el que se produzcan estas acciones, acontecimiento que resultará determinante a la hora de destacar la importancia que se le infiere al caso concreto ${ }^{11}$.

\section{La delincuencia sexual en España}

Como ya se ha señalado anteriormente, las agresiones sexuales se encuentran desarrolladas en el Capítulo I del Título VIII del Código Penal, el cual hace referencia a los delitos contra la libertad e indemnidad sexual. En este sentido, cabe destacar que, dentro del citado Título, además de los delitos a los cuales se hace referencia en este epígrafe, vienen detallados otras infracciones de gran importancia, tales como: los abusos sexuales, ya sean cometidos contra adultos o contra menores de edad; el acoso sexual; el exhibicionismo y la provocación sexual, así como las acciones relativas a la prostitución y a la explotación y corrupción de menores.

8 SÁINZ-CANTERO CAPARRÓS, J. E., «De los delitos contra la libertad e indemnidad sexuales (I)», en Morillas Cueva (Coord.), Sistema de Derecho Penal Español. Parte Especial, Madrid, 2011, pág. 239.

9 Ibidem, pág. 240.

10 Morillas Fernández, D. L., «Los delitos contra la libertad e indemnidad sexuales», en Morillas Cueva (Dir.), Estudios sobre el Código Penal reformado. (Leyes Orgánicas 1/2015 y 2/2015), Madrid, 2015, pág. 434.

11 Muñoz Conde, F., Derecho penal: parte especial, Valencia, 2019, pág.203-205. 
En lo que respecta a esta investigación, resulta relevante destacar que la misma se va a centrar en el delito de agresión sexual agravado (violación), el cual tiene su origen en el artículo 179 del Código Penal. No obstante, en aras de proceder a un mejor entendimiento del mismo, así como del resto del articulado referente a los delitos contra la libertad e indemnidad sexual, se estima ineludible hacer una breve referencia a cada uno de las mencionadas infracciones penales.

\section{a. Abuso sexual.}

En referencia a estos delitos, cabe destacar que aparece regulado en el Capítulo II (cuando el sujeto pasivo es una persona mayor de dieciséis años) y en el Capítulo II bis (el cual hace referencia a los delitos de abusos y agresiones sexuales cometidos contra menores de dicha edad).

Así, cabe destacar que el artículo 181.1 del Código Penal establece que será castigado como reo de abuso sexual «el que, sin violencia o intimidación y sin que medie consentimiento, realizare actos que atenten contra la libertad e indemnidad sexual de otra persona». Por otro lado, el artículo 181.2 hace referencia a los supuestos donde no existirá consentimiento, tales como: «los que se ejecuten sobre personas que se hallen privadas de sentido o de cuyo trastorno mental se abusare, así como los que se comentan anulando la voluntad de la víctima mediante el uso de fármacos, drogas o cualquier otra sustancia natural o química idónea a tal efecto».

Posteriormente, el artículo 182 del Código Penal versa sobre las acciones cometidas contra menores con edades comprendidas entre los dieciséis y los dieciocho años. Así, dicho apartado habla sobre la realización de este delito a través del engaño o del abuso de confianza, autoridad o influencia.

A tenor de lo redactado anteriormente, se puede apreciar como existe una gran dificultad a la hora de determinar la gravedad idónea para señalar cuándo estamos frente a un delito de abuso sexual, pudiendo llegar a confundir tales acciones con otras conductas de menor trascendencia o entidad ${ }^{12}$.

Los abusos sexuales cometidos contra menores de edad presentan una especial significación, ya que la comisión de estas acciones delictivas puede llegar a dejar en los infantes unas secuelas psicológicas que perdurarán en los mismos durante el resto de sus vidas. Así, este acontecimiento puede verse reflejado a la hora de llevar a cabo el proceso penal, ya que estos delitos suelen ser ejecutados en soledad,

12 Pérez Alonso, E., «Concepto de abuso sexual: contenido y límite mínimo del delito de abusos sexuales», en InDret. Revista para el Análisis del Derecho, 3/2019, 2019, págs. $1-43$. 
donde el agresor y la víctima son los únicos sujetos presentes, convirtiéndose ésta en «la persona con mayor relevancia probatoria» ${ }^{13}$.

Echeburúa Odriozola y De Corral Gargallo establecen una definición concreta a la hora de referirse a los delitos de abusos sexuales cometidos sobre menores de edad. Así, dichos investigadores afirman que será «cualquier conducta sexual mantenida entre un adulto y un menor. Más que la diferencia de edad, lo que define el abuso es la asimetría entre los implicados en la relación y la presencia de coacción» ${ }^{14}$.

Ropero Carrasco habla sobre la dificultad que se genera en torno a estos delitos a la hora de llegar a entender la repercusión que generan. Así, dicha investigadora también hace referencia a la importante cifra sumergida de abusos sexuales, destacando que «existe una realidad delincuencial que ha permanecido silenciada, oculta» ${ }^{15}$.

En un intento por definir las pautas de actuación y las medidas a adoptar en los supuestos en los que se produzcan este tipo de infracciones penales contra menores de edad, se firma en el año 2010 el Convenio de Lanzarote, del Consejo de Europa, para la protección de los niños contra la explotación y el abuso sexual. Así, en dicho acuerdo se establece que «todas las formas de abuso sexual infantil, incluidos los actos cometidos en el extranjero, ponen en grave peligro la salud y el desarrollo psicosocial del niño».

\section{b. Acoso sexual.}

Este delito viene regulado en el artículo 184 del Código Penal y hace referencia a aquellas acciones en las que se solicitan favores de naturaleza sexual dentro de tres ámbitos concretos, ya sea en un contexto laboral, académico o de prestación de servicios. Dicho artículo también refleja la necesidad de que los mencionados quehaceres deban realizarse de forma continuada o habitual, llegando a provocar en el sujeto pasivo una situación gravemente intimidatoria, hostil o humillante.

Posteriormente, el segundo punto de dicho precepto se refiere a la realización de tales acciones aprovechándose el culpable de una situación de superioridad dentro de los contextos anteriormente citados, o mediante el anuncio de un mal relacionado con las lícitas expectativas de la víctima.

13 Cano Cuenca, A., «Tratamiento práctico de los delitos contra la libertad sexual. Especial referencia a los abusos sexuales a menores», en Roig Torres (Dir.), Tratamiento Penal de la delincuencia sexual. Comparativa entre los sistemas norteamericano y europeo, Valencia, 2014, pág. 85.

14 Echeburúa Odriozola, E., y De Corral Gargallo, P., «Secuelas emocionales en víctimas de abuso sexual en la infancia», en Cuadernos de Medicina Forense, Vol. 12, 2006, págs. 75-82.

15 Ropero Carrasco, J., «Reformas penales y política criminal en la protección de la indemnidad sexual de los menores. El proyecto de 2013», en Estudios Penales y Criminológicos, Vol. XXXIV, 2014, pág. 233. 
Finalmente, el último apartado del mencionado artículo hace referencia a los supuestos en los que la víctima sea una persona especialmente vulnerable, por razón de edad, enfermedad o situación.

En este sentido, se puede apreciar cómo en el delito de acoso sexual la pareja penal puede estar conformada por cualquier individuo, con independencia del sexo, siempre que cumplan con los requisitos anteriormente descritos. No obstante, la definición aportada por el Código Penal nos muestra una realidad laboral, donde se entiende que ambos sujetos pueden estar situados en una posición profesional idéntica; donde uno de los dos miembros presente una situación de superioridad sobre el otro; o, finalmente, donde la infracción sea cometida por un subordinado, siendo la víctima un dirigente.

A tenor de la definición aportada por el Código Penal, nos encontramos ante un delito de difícil apreciación social. Así, a modo de ejemplo, en un estudio llevado a cabo sobre 1.693 personas del ámbito universitario; ya sean alumnos, profesores o personal de administración, se observó cómo la percepción de este delito fue desigual dependiendo del sexo y de la situación laboral que ocupaba la persona encuestada dentro de la universidad ${ }^{16}$.

\section{c. Exhibicionismo y provocación sexual.}

El artículo 185 del Código Penal establece que serán castigados con la pena de prisión de seis meses a un año o multa de 12 a 24 meses quien «ejecutare o hiciere ejecutar a otra persona actos de exhibición obscena ante menores de edad o persona con discapacidad necesitada de especial protección».

Por otro lado, el siguiente artículo sanciona con idéntica pena al sujeto que «por cualquier medio directo, vendiere, difundiere o exhibiere material pornográfico entre menores de edad o personas con discapacidad necesitadas de especial protección». En este sentido, la descripción del tipo aclara que dicho precepto hace referencia exclusivamente al hecho de hacer llegar a otro individuo este tipo de material, dejando de lado aquellos actos orientados a la creación de los mismos.

A la hora de extraer las principales características de dichos artículos, se configura como esencial la determinación de los diferentes participantes en dichos actos, así como la aclaración del término «exhibición obscena» que se utiliza para esclarecer el delito de exhibicionismo. En este sentido, haciendo referencia a la primera problemática planteada, el Código Penal establece de forma clara quienes podrían ser catalogados como víctimas de estos delitos (menores o persona discapacitada necesitada de especial protección). Por otro lado, en lo

16 Ferrer Pérez, V.A., y Bosch Fiol, E., «La percepción del acoso sexual en el ámbito universitario», en Revista de Psicología Social, Vol. 29, 2014, págs. 462-501. 
referente a los sujetos activos del mismo, se entiende que podrá ser cualquier individuo mayor de edad, con independencia del sexo, ya que, si el sujeto culpable fuera menor podría ser sancionado por la Ley Orgánica de responsabilidad penal de los menores, siempre que tuviera entre 14 y 18 años, o llegar a quedar impune si presenta una edad inferior a la anteriormente citada.

Ante tales afirmaciones, se considera conveniente destacar la posible problemática existente a la hora de comprender la función otorgada por el Código al término «obsceno». En consecuencia, Muñoz Conde establece que es un concepto que tiene una relación directa con «determinadas pautas morales convencionales que disciplinan el comportamiento sexual de las personas» ${ }^{17}$. Así, dicho autor utiliza el constructo «moral sexual social» ${ }^{18}$ para esclarecer lo anteriormente descrito.

En referencia a la importancia que presenta la determinación de estos delitos, Sáinz-Cantero Caparrós afirma que «nuestro sistema penal, pese a las muchas críticas recibidas en su día, mantiene la criminalización de esas conductas «provocadoras» en el ámbito sexual; y además lo hace, con razón, limitando su intervención a aquellas que pueden afectar a menores o personas con discapacidad, en lo que coincide con las principales líneas asentadas desde el punto de vista supranacional para la protección de menores en este ámbito» ${ }^{19}$.

\section{d. Prostitución, explotación sexual y corrupción de menores.}

Los artículos comprendidos entre el 187 y el 190 del Código Penal hacen referencia expresa a las transgresiones mencionadas en este precepto. Así, cada una de las infracciones aludidas presenta una serie de características propias que clarifican la funcionalidad de cada una de ellas.

Orts Berenguer afirma que dichos artículos se encuentran recogidos en el Capítulo V del Código Penal, el cual ha sido reformado en diferentes ocasiones, precisamente para intentar adaptar esta tipología delictiva a los diferentes cambios que se producen en la sociedad. Así, dicho investigador establece que estos delitos estarán pensados «especialmente para la tutela de menores y de personas con discapa-

\footnotetext{
17 Muñoz Conde, F., Derecho Penal... cit., pág. 233.

18 Muñoz Conde afirma que dicho término podría hacer referencia a «aquella parte del orden moral social que encauza dentro de unos límites las manifestaciones del instinto sexual de las personas. Esto no significa que sea la «moral sexual» el bien jurídico protegido en esta materia. Es más, cualquier intento de convertir la moral sexual» como tal, sin identificar los concretos bienes jurídicos que pueden ser específicamente cuestionados en los respectivos tipos delictivos, en un bien jurídico protegido autónomo conlleva el peligro de convertir el Derecho penal en esta materia en un instrumento ideológico más propio de la Inquisición que de un moderno Estado pluralista y democrático».

Ibidem, pág. 205.

19 Sáinz-Cantero Caparrós, J. E., «De los delitos contra la libertad... cit., pág. 275.
} 
cidad frente a su utilización y explotación con fines exhibicionistas o pornográficos y en el ejercicio de la prostitución» ${ }^{20}$.

La determinación de la prostitución como delito lleva aparejada una gran dificultad dentro de un contexto jurídico y criminológico. En este sentido, cabe destacar que la acción de prostituirse no estaría castigada en nuestro Código, siendo requisitos esenciales para que se produzcan tales acontecimientos legislativos la concurrencia de diversas actuaciones cuyo fin último sea el de promover el favorecimiento de dicho acto.

El uso por parte del delincuente de violencia, intimidación o engaño, partiendo de un contexto en el que se produce una situación de superioridad, necesidad o vulnerabilidad de la víctima, son requisitos indispensables para la calificación de un delito de prostitución.

Serrano Gómez y Serrano Maíllo, al hablar sobre las principales características que engloban a la definición de prostitución, afirman que «será ejercida de forma más o menos permanente, que suele llegar a convertirse en un modo de vida, por lo que han de excluirse los actos aislados ${ }^{21}$. En este sentido, dichos investigadores destacan la reiteración de acciones, no siendo posible acuñar con dicho término aquellas acciones que se realicen de forma excepcional.

En lo que respecta a la pornografía infantil, las diferentes reformas producidas en el articulado del Código Penal han provocado la adaptación de diversos ilícitos a las necesidades operadas por parte de la Unión Europea. En este sentido, los delitos contra la libertad e indemnidad sexuales también han sido reformados con la intención de poder castigar a los infractores y encontrar un amparo jurídico a las víctimas de este tipo de acontecimientos criminales. Por su parte, la Directiva 2011/92/UE del Parlamento Europeo estableció diferentes pautas de comportamiento para poder esclarecer cuando nos encontramos ante un delito de pornografía infantil. Dichas exigencias europeas vienen reflejadas en el artículo 189.2 y establecerá los siguientes requisitos:

1. Todo material que represente de manera visual a un menor participando en una conducta sexualmente explícita real o simulada;

2. Toda representación de los órganos sexuales de un menor con fines principalmente sexuales;

3. Todo material que represente de forma visual a una persona que parezca ser un menor participando en una conducta sexualmente explícita real o simulada o cualquier representa-

20 Orts Berenguer, E., «Delitos contra la libertad e indemnidad sexuales (y III): Exhibicionismo y provocación sexual. Prostitución, explotación sexual y corrupción», en Derecho Penal. Parte Especial, Valencia, 2019, pág. 254.

21 Serrano Gómez, A., y Serrano Maíllo, A., «Delitos contra la libertad e indemnidad sexual (II)», en Curso de Derecho Penal. Parte Especial, Madrid, 2019, pág. 189. 
ción de los órganos sexuales de una persona que parezca ser un menor, con fines principalmente sexuales;

4. Imágenes realistas de un menor participando en una conducta sexualmente explícita o imágenes realistas de los órganos sexuales de un menor, con fines principalmente sexuales.

En este sentido, Morillas Fernández atestigua que «el concepto de pornografía infantil ha sufrido una evolución en los últimos años siendo la tendencia actual de los órganos, instituciones y legislaciones internacionales relacionar la citada acepción con el requisito de la conducta sexual explícita [...]. A tal efecto creo que ha llegado el momento de cambiar la antigua concepción de pornografía infantil mantenida en nuestro país a favor de la conducta sexual explícita y la consiguiente diferenciación entre pornografía y erotismo» ${ }^{22}$.

\section{Agresiones sexuales: especial consideración hacia las violaciones}

En la actualidad, las agresiones sexuales están teniendo una gran repercusión social a través de las noticias emitidas en los medios de comunicación como consecuencia de las recientes acciones cometidas por determinados grupos de personas que se congregan para cometer este tipo de infracciones.

En este sentido, se podría afirmar que estos delitos, además de la ya mencionada alarma social, generan un malestar en los vínculos personales existentes entre hombres y mujeres, pudiendo llegar a provocar en estas últimas un sentimiento de incomodidad persistente cuando se encuentran acompañadas por personas de sexo masculino. Así, Redondo Illescas y Garrido Genovés afirman que «la violación y los demás delitos contra la libertad sexual tendrían, por tanto, repercusiones sociales perniciosas y restrictivas más allá de las directamente ocasionadas a las víctimas concretas de las agresiones. Además, este es un problema que no solamente preocupa a las mujeres, sino que, en un sentido más amplio, influye negativamente en las relaciones entre mujeres y hombres en general» ${ }^{23}$.

Ante la ineludible intervención por parte de los órganos judiciales cuando se producen este tipo de acciones delictivas, así como las constantes peticiones de actuación por parte de los medios de comunicación, Muñoz Conde y García Arán consideran que «el orden jurídico se pre-

22 Morillas Fernández, D.L., Análisis dogmático y criminológico de los delitos de pornografía infantil. Especial consideración de las modalidades comisivas relacionadas con Internet, Madrid, 2005, pág. 461.

23 Redondo Illescas, S., y Garrido Genovés, V., Principios... cit., pág. 690. 
senta como un medio de represión del individuo y, por tanto, como un medio violento, justificado sólo en tanto sea un medio necesario para posibilitar la convivencia» ${ }^{24}$.

En referencia a la mencionada incidencia de estos hechos delictivos en la opinión pública, Larrauri Pijoan afirma que «este es un tipo de delincuencia muy presente en los medios de comunicación y quizás más en la actualidad debido a la confluencia de cambios culturales y desarrollos tecnológicos, aun cuando no es seguro si ha aumentado o se ha incrementado la definición de nuevos comportamientos» ${ }^{25}$.

Hay que tener en cuenta que estos delitos presentan un amplio recorrido en nuestra legislación penal, no siendo acciones novedosas para la justicia española. Así, a modo de ejemplo, se puede observar cómo el Código Penal de 1848 englobaba estos delitos bajo el Título «Delitos contra la honestidad». En este sentido, Asua Batarrita considera que lo establecido en dicha recopilación normativa se mantuvo vigente «en lo sustancial» hasta $1996^{26}$.

Como se puede apreciar, estos delitos son acciones que se insertan en el pasado, presente y futuro de nuestra legislación punitiva. Actualmente, como ya se ha destacado anteriormente, y tras la última modificación del Código Penal, este tipo de infracciones puede contemplarse en los artículos 178, 179 y 180. Así, en referencia al primero de ellos, se establece que para ser condenado por un delito de agresión sexual el delincuente debe atentar contra la libertad sexual del sujeto pasivo, utilizando para lograr su propósito delictivo violencia o intimidación.

Posteriormente, el siguiente artículo hace referencia a aquellos individuos que deben de ser castigados como reos de un delito de violación, ya que para llevar a cabo la acción criminal el sujeto deberá realizar el acto mediante acceso carnal, ya sea por vía vaginal, anal o bucal, o a través de la introducción de miembros corporales u otros objetos por alguna de las dos primeras vías anteriormente descritas.

Respecto a este tipo de acciones delictivas, como se puede apreciar en el siguiente gráfico, y teniendo en cuenta los datos extraídos en el portal estadístico de criminalidad emitido por el Ministerio del Interior, las agresiones sexuales simples son más numerosas que las violaciones en la última década, existiendo una amplia diferencia en torno a las mismas,

24 Muñoz Conde, F., y García Arán, M., Derecho Penal. Parte General, Barcelona, 2015, pág. 34.

25 Larrauri PiJOAN, E., Introducción a la criminología y sistema penal, Madrid, 2018, pág. 93.

26 Asua Batarrita, A., «Las agresiones sexuales en el nuevo Código Penal: Imágenes culturales y discurso jurídico», en Análisis del Código Penal desde la perspectiva de género, Vitoria - Gazteiz, 1998, pág. 60. 
habiendo sido cometida la primera de ellas en 15.189 ocasiones, mientras que la segunda lo fue en 10.771 veces.

Gráfico 1. Agresiones sexuales y violaciones en España (2010-2018)

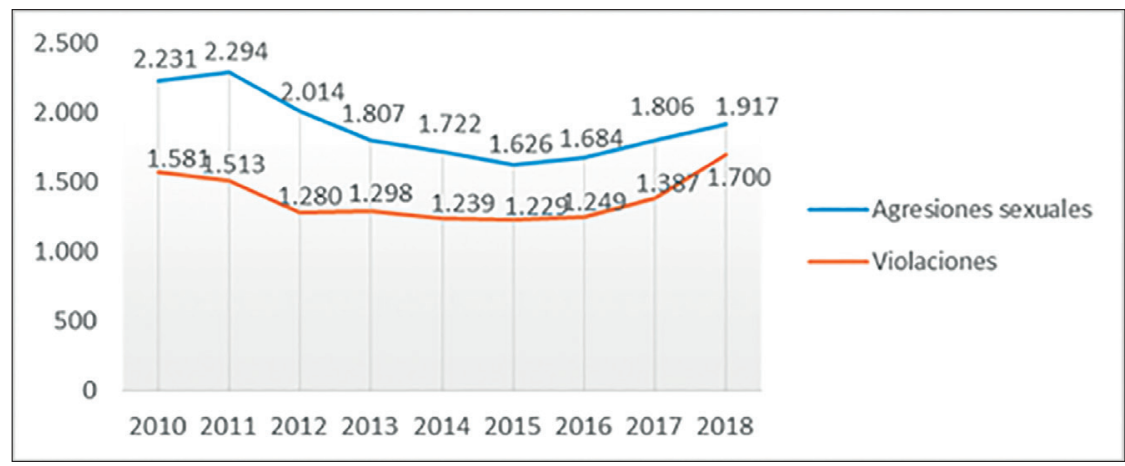

Fuente: Elaboración propia a partir de los datos extraídos del

Ministerio del Interior en la página web https://estadisticasdecriminalidad.ses.mir.es/

En referencia a la incidencia de este tipo de infracciones durante la niñez, diferentes investigaciones han concluido que existe un número elevado de sucesos en los que un agresor sexual adulto ha sido víctima de alguno de los delitos descritos contra la delincuencia sexual durante la etapa infantil ${ }^{27}$.

Groth, Burgess y Holmstrom señalan que los agresores sexuales presentan tres características básicas que los distinguen del resto de delincuentes violentos. Así, estos autores señalan que la hostilidad, el poder y la sexualidad germinarán en aquellas personas que vayan a realizar, o que hayan cometido, este tipo de acciones. No obstante, también señalan que dichas peculiaridades se desarrollarán de forma distinta en cada individuo, variando de un sujeto a otro ${ }^{28}$.

A modo de ejemplo, y para demostrar la incidencia de estos delitos, traigo a colación las afirmaciones expuestas por los investigadores McKibbin, Shackelford, Goetz y Starratt, quienes llevaron a cabo un estudio minucioso sobre la influencia de las violaciones dentro de la sociedad

27 Barbaree, H. E., and Langton, C. M., «The effects of child sexual abuse and family environment», en Barbaree and Marshall (Eds.), The juvenile sex offender, New York, 2006, págs. 58-76.; HeNDRIKS, J., and BiJleVEld, C. C., "Juvenile sexual delinquents: contrasting child abusers with peer abusers", en Criminal Behaviour and mental health, vol. 14, 2004, págs. 238-250.

28 Groth, A. N., Burgess, W., and Holmstrom, L. L., «Rape: Power, anger and sexuality», en American Journal of Psychiatry, vol. 134, 1977, págs. 1239-1243. 
norteamericana. Así, estos autores afirman que esta tipología delictiva presenta unos porcentajes de comisión muy elevados. No obstante, dichas cifras deberían ser superiores, ya que se estima que «entre el 67$84 \%$ de las violaciones no son denunciadas» 29 .

En este sentido, Turvey, en un intento por demostrar cuales son las motivaciones que guían a una persona a cometer una acción delictiva de estas características, afirma que «el motivo es la necesidad general, y la intención es el plan específico. Muchas violaciones se cometen para satisfacer la necesidad emocional o psicológica de un violador de expresar poder, ira o deseo sádico» ${ }^{30}$.

\section{Análisis jurídico-criminológico: creación de un perfil}

Con esta investigación se pretende extraer las características principales que posibiliten la creación de un perfil criminal orientado a los violadores en serie que actúan en España. Para ello, resulta fundamental proceder a distinguir entre aquellos sujetos que han cometido dos, tres o más violaciones. En consecuencia, desde una perspectiva jurídica y criminológica, los gráficos que se detallan en este epígrafe se centran en el análisis de los individuos que cometen el mencionado tipo delictivo.

En este sentido, la investigación de un conjunto de sentencias condenatorias, las cuales he considerado oportuno dividir en $\operatorname{dos}^{31}$, tres ${ }^{32} \mathrm{O}$

29 Mckibiin, W.F., Shackelford, T., Goetz, A.t., and Starrarr, V.g., "Why do men rape? An evolutionary psychological perspective», en Review of General Psychology, Vol. 12, 2008 , págs. 86-97.

30 Turvey, B.E., Criminal profiling. An introduction to behavioral evidence analysis, New York, 2014, pág. 487.

31 Sentencia de la Audiencia Provincial de León 4/2003, de 16 de mayo [JUR\2003 232768]; Sentencia de la Audiencia Provincial de Girona 195/2004, de 4 de marzo [JUR\2004\156042]; Sentencia de la Audiencia Provincial de Madrid 32/2004, de 31 de marzo [JUR\2004\248319]; Sentencia de la Audiencia Provincial de Castellón 20/2004, de 1 de octubre [JUR\2004\300830]; Sentencia de la Audiencia Provincial de Murcia 30/2006, de 26 de junio [JUR\2006\202492]; Sentencia de la Audiencia Provincial de Zaragoza 59/2006, de 27 de julio [JUR\200739852]; Sentencia de la Audiencia Provincial de Madrid 2/2007, de 10 de enero [JUR\2007160409]; Sentencia de la Audiencia Provincial de Jaén 17/2007, de 1 de febrero [JUR 2007265871]; Sentencia de la Audiencia Provincial de A Coruña 17/2012, de 24 de abril [JUR\2012\170052]; Sentencia de la Audiencia Provincial de Murcia 236/2012, de 23 de mayo [JUR\2012245047]; Sentencia de la Audiencia Provincial de Madrid 450/2014, de 18 de junio [ARP 2014\1116]; Sentencia de la Audiencia Provincial de Valencia 157/2016, de 30 de marzo [ARP 2016 865 ]; Sentencia de la Audiencia Provincial de Valladolid 138/2016, de 11 de mayo [JUR\2016138630]; Sentencia de la Audiencia Provincial de Zaragoza 11/2018, de 8 de enero [JUR 2018\46847]; Sentencia de la Audiencia Provincial de Madrid 410/2018, de 20 de junio [JUR\2018\231239].

32 Sentencia de la Audiencia Provincial de Murcia 112/1999, de 15 de septiembre [JUR\1999\273251]; Sentencia de la Audiencia Provincial de Cádiz 28/2000, de 2 de noviembre [JUR\2001\46446]; Sentencia de la Audiencia Provincial de Asturias 34/2003, de 30 de enero [JUR $2003 \backslash 115420$ ]; Sentencia de la Audiencia Provincial de Madrid 
más hechos delictivos ${ }^{33}$, resulta eficaz para extraer aquellos datos que se podrían considerar óptimos para el análisis de estos criminales. En consecuencia, como detalle relevante a subrayar, cabe destacar que todos los escritos judiciales estudiados hacen referencia a agresores de sexo masculino, con independencia del número de violaciones cometidas.

\subsection{Victimas de las violaciones}

En referencia a las personas que se consideran sujetos pasivos de aquellos agresores que han cometido dos delitos de violación, como se puede apreciar en el siguiente gráfico, existe una amplia mayoría de mujeres entre las víctimas de los individuos que se insertan en esta tipología delictiva.

\section{Gráfico 2. Víctimas de dos delitos de violación $(\mathrm{n}=15)$}

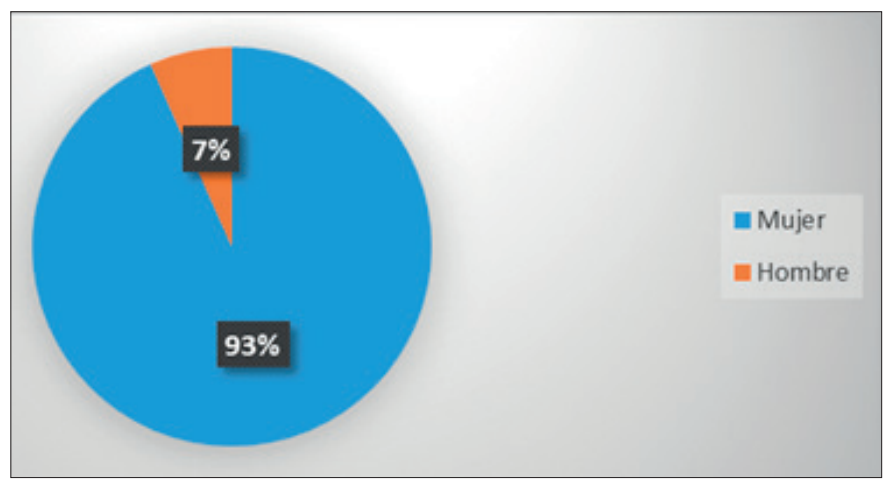

Fuente: Elaboración propia a partir de la jurisprudencia analizada sobre dos delitos de violación

32/2004, de 31 de marzo [JUR 2004\248319]; Sentencia de la Audiencia Provincial de Sevilla 201/2004, de 17 de mayo [JUR 2004\199283]; Sentencia de la Audiencia Provincial de Madrid 303/2004, de 3 de junio [ARP\2004\588]; Sentencia de la Audiencia Provincial de Sevilla 30/2006, de 8 de febrero [JUR 2006\180557]; Sentencia de la Audiencia Provincial de Valencia 648/2008, de 27 de octubre [ARP 2009\61]; Sentencia de la Audiencia Provincial de Madrid 275/2009, de 19 de junio [JUR\2009\364855]; Sentencia de la Audiencia Provincial de Las Palmas 86/2009, de 30 de junio [JUR 2009\1186]; Sentencia de la Audiencia Provincial de Madrid 565/2015, de 13 de julio [ARP\2016\428].

33 Sentencia de la Audiencia Provincial de Soria 18/1996, de 3 de abril [ARP $\backslash 1996 \backslash 767]$; Sentencia de la Audiencia Provincial de Valencia 36/1998, de 3 de febrero [ARP $\backslash 1998 \backslash 1288$ ]; Sentencia de la Audiencia Provincial de Zaragoza 62/2002, de 8 de marzo [JUR 2002\118740]; Sentencia de la Audiencia Provincial de Baleares 55/2005, de 28 de abril [JUR\2005\122049]; Sentencia de la Audiencia Provincial de Murcia 36/2005, de 11 de julio [ARP\2005\626]; Sentencia de la Audiencia Provincial de Baleares 47/2006, de 7 de junio [ARP\2006\597]; Sentencia de la Audiencia Provincial de Navarra 44/2008, de 5 de marzo [ARP\2008\418]; Sentencia de la Audiencia Provincial de Madrid 485/2008, de 9 de octubre [ARP 2009\817]; Sentencia de la Audiencia Provincial de A Coruña 36/2009, de 30 de octubre [JUR 2011 55981];Sentencia de la Audiencia Provincial de Madrid 1345/2010, de 9 de diciembre [ARP $2011 \backslash 762$ ]; Sentencia de la Audiencia Provincial de Barcelona 148/2017, de 27 de febrero [JUR $2017 \backslash 125958$ ]. 
Por otro lado, debido a que en los supuestos analizados con tres víctimas todas ellas eran mujeres, el análisis jurisprudencial nos lleva a analizar aquellos casos en los que se han producido cuatro o más acontecimientos delictivos relacionados con las infracciones propias del estudio que se está realizando. Así, en el siguiente gráfico, se puede observar cómo las mujeres vuelven a presentar unas cifras superiores a los hombres. En este sentido, cabe destacar el incremento de acciones acometidas sobre personas del sexo masculino, aumentando en más de un $25 \%$ respecto a las cifras obtenidas en los supuestos en los que se llevaban a cabo dos acciones criminales.

\section{Gráfico 3. Víctimas de cuatro o más delitos de violación $(n=42)$}

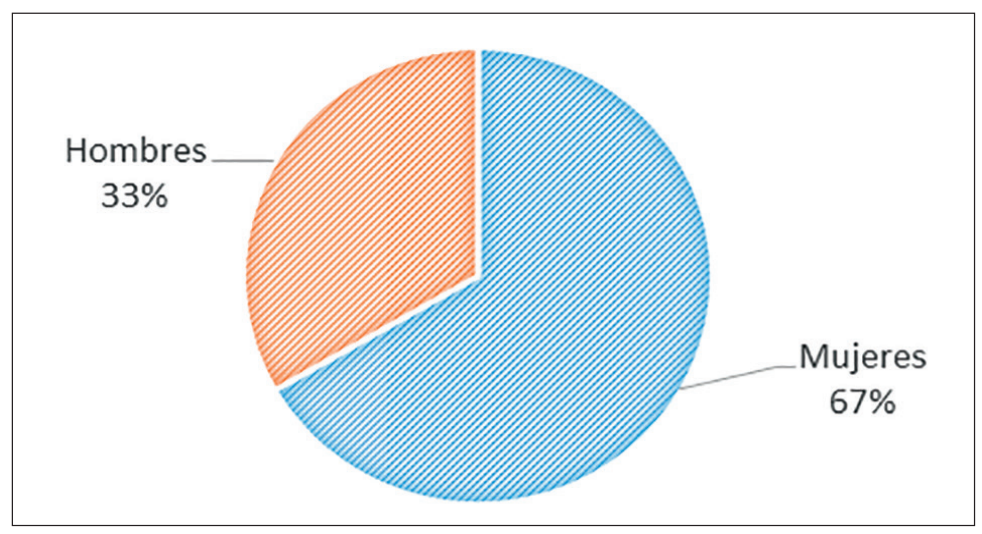

Fuente: Elaboración propia a partir de la jurisprudencia analizada sobre cuatro o más delitos de violación

Continuando con el estudio de las víctimas, un dato especialmente relevante es aquel que versa sobre el conocimiento previo por parte del infractor respecto al sujeto pasivo de estos delitos. Así, los gráficos que se muestran a continuación exteriorizan datos claramente diferenciados, revelando una gran controversia en el estudio de dicha variable.

En este sentido, el siguiente gráfico, el cual hace referencia a aquellos casos en los que el agresor ha cometido dos infracciones, muestra cómo existirá un mayor porcentaje de acontecimientos en los que el delincuente y su víctima se conocían con anterioridad al momento temporal en el que se cometió dicho acto. 


\section{Gráfico 4. Víctimas conocidas en dos delitos de violación $(n=15)$}

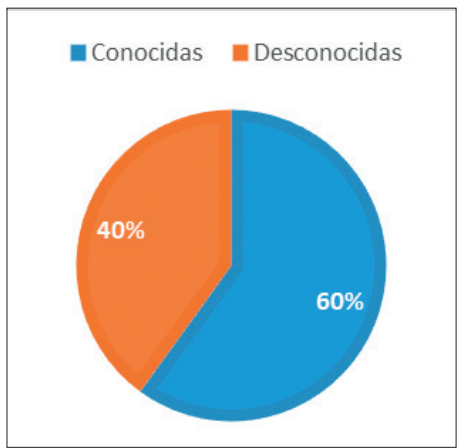

Fuente: Elaboración propia a partir de la jurisprudencia analizada sobre dos delitos de violación

En consecuencia, los investigadores Waterhouse, Reynolds y Egan, en referencia a los estudios realizados sobre las violaciones denunciadas a las autoridades británicas, establecieron una tipología delictiva en base a la relación existente entre el sujeto activo y su víctima. Así, dichos autores instauraron cuatro tipos claramente diferenciados:

a. Doméstica. Existe, o ha existido, una relación sexual entre agresor y víctima, aunque dicho trato haya sido casual.

b. Conocidos. Ambos sujetos se conocían con anterioridad, no siendo necesario una relación sexual previa. Estos autores ponen como ejemplo en este apartado a los familiares, amigos, compañeros de trabajo o vecinos, entre otros.

c. Desconocidos. Como su propio nombre indica, son situaciones en las que ambos sujetos no se conocían previamente, o habían pasado muy poco tiempo juntos. En consecuencia, estos autores establecen subcategorías dentro de esta tipología: I) extraños conocidos. Agresor y víctima habían tenido un contacto previo, el cual no superaba las 24 horas; II) extraños reconocidos. Aunque no existía una relación anterior, el sujeto pasivo conocía a su futuro agresor por ser un familiar o allegado de un conocido de este; III) extraños. Delincuente y víctima nunca habían coincidido, por lo que no existía un contacto previo de ningún tipo.

d. Vulnerables. El violador se encuentra en una posición de poder o responsabilidad sobre la víctima ${ }^{34}$.

34 Waterhouse, G.F., Reynolds, A., and Egan, V., "Myths and legends: The reality of rape offences reported to a UK police force», en The European Journal of Psychology Applied to Legal Context, vol. 8, 2016, págs. 1-10. 
Por otro lado, en lo referente a aquellas sentencias que hacen referencia a tres acontecimientos criminales, en el siguiente gráfico se puede apreciar una gran mayoría de sucesos donde no existe una relación previa entre el agresor y su víctima, ocurriendo en el 90,90\% de los casos analizados.

\section{Gráfico 5. Víctimas conocidas en tres delitos de violación $(n=11)$}

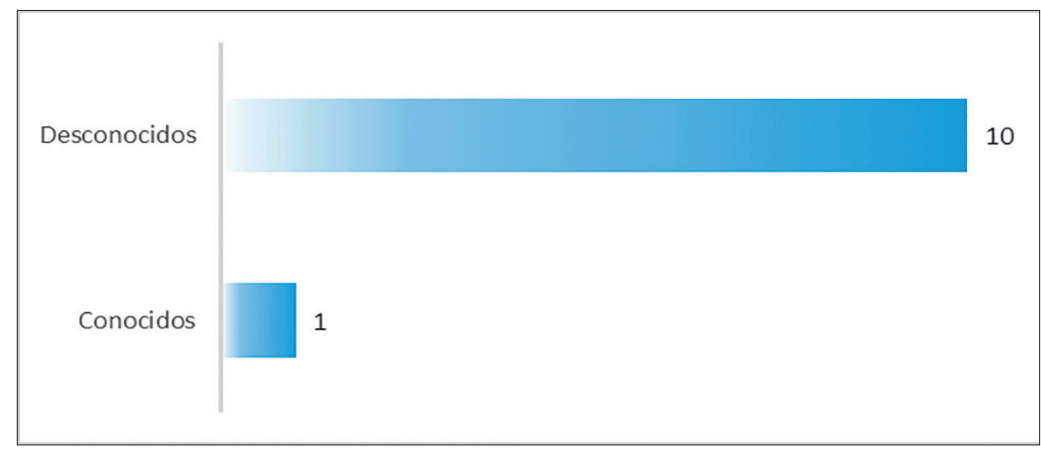

Fuente: Elaboración propia a partir de la jurisprudencia analizada sobre tres delitos de violación

Finalmente, en aquellos supuestos en los que se han producido cuatro o más violaciones, existe una mayoría de casos en los que no concurre una relación anterior al acontecimiento delictivo. No obstante, cabe destacar que los porcentajes mostrados no son tan desmedidos como los exteriorizados para los casos en los que se producen tres actos criminales.

\section{Gráfico 6. Víctimas conocidas en cuatro o más delitos de violación $(n=42)$}

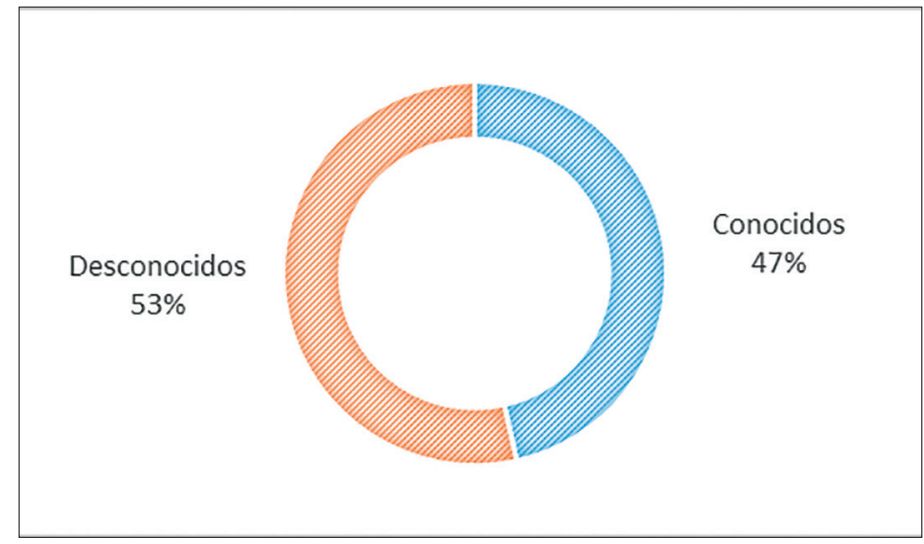

Fuente: Elaboración propia a partir de la jurisprudencia analizada sobre cuatro o más delitos de violación 
En consecuencia, una vez analizada la existencia o no de un conocimiento previo entre el sujeto activo y pasivo, el análisis jurisprudencial nos permite estudiar si la intencionalidad de estos criminales en sus actuaciones delictivas iba encaminada a dañar a una sola víctima o si, en cambio, presentaban el propósito de perjudicar a más de una persona.

En este sentido, a continuación, se puede apreciar cómo en aquellos sucesos en los que se han llevado a cabo dos o tres violaciones, los agresores actuaban, como regla general, sobre la misma víctima para intentar saciar su instinto delictivo-sexual. En consecuencia, se observa cómo existe una amplia mayoría de acontecimientos que se centran en dañar a una única víctima.

\section{Gráfico 7. Única o varias víctimas en dos y tres delitos de violación $(n=15$ y $n=11)$}

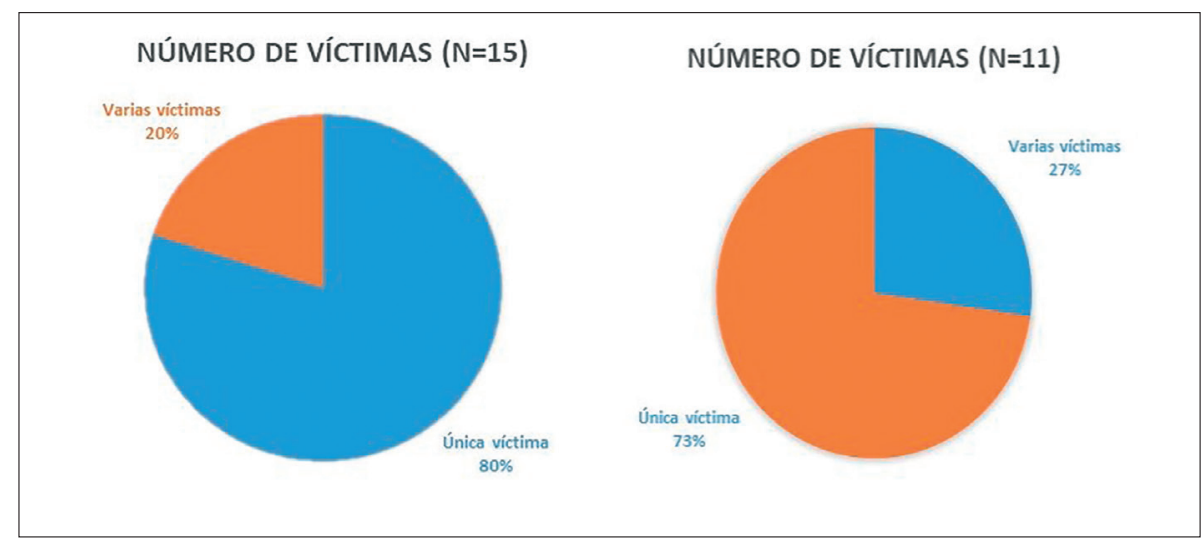

Fuente: Elaboración propia a partir de la jurisprudencia analizada sobre dos y tres delitos de violación

Por otro lado, a diferencia de lo que ocurría con las acciones analizadas en el gráfico anterior, los datos relativos a los acontecimientos realizados en cuatro o más ocasiones exteriorizan unos porcentajes desiguales a los mencionados, ya que, en este caso concreto, los criminales suelen actuar sobre varias víctimas, no centrando todos sus esfuerzos en perjudicar a una sola persona. 


\section{Gráfico 8. Única o varias víctimas en cuatro o más delitos de violación $(\mathrm{n}=11)$}

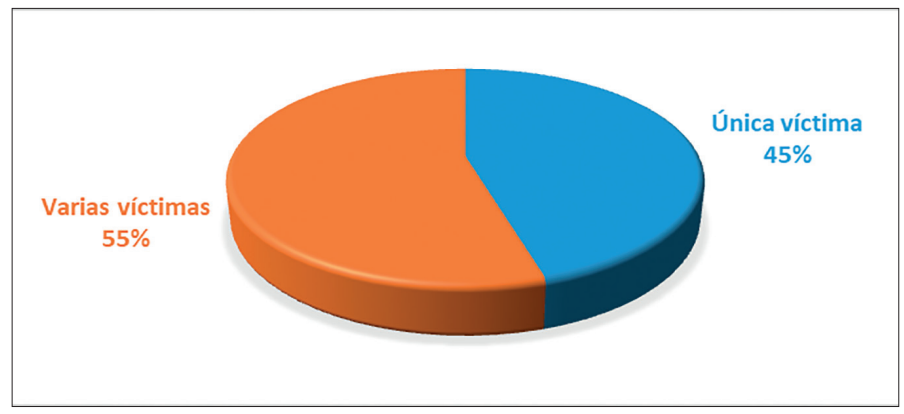

Fuente: Elaboración propia a partir de la jurisprudencia analizada sobre cuatro o más delitos de violación

Finalmente, en lo que respecta al estudio de las víctimas de esta tipología delictiva, considero fundamental proceder al análisis de la edad de las mismas, ya que puede aportar información altamente relevante relacionada con la probabilidad de sufrir estos tipos de acciones violentas.

En consecuencia, en el siguiente gráfico se muestran los datos relacionados con las víctimas que han sufridos dos $(\mathrm{n}=10)$ o tres $(\mathrm{n}=8)$ acontecimientos delictivos. En este sentido, se puede apreciar cómo unos y otros muestran una particularidad clara, y es que los porcentajes concernientes a la mayoría o minoría de edad revelan la existencia de una consonancia entre ambas variables, sin importar el número de acontecimientos delictivos sufridos, representando cada uno de los mencionados grupos de edad el $50 \%$ de los casos totales.

\section{Gráfico 9. Edad de las víctimas en dos y tres delitos de violación $(n=8$ y $n=10)$}

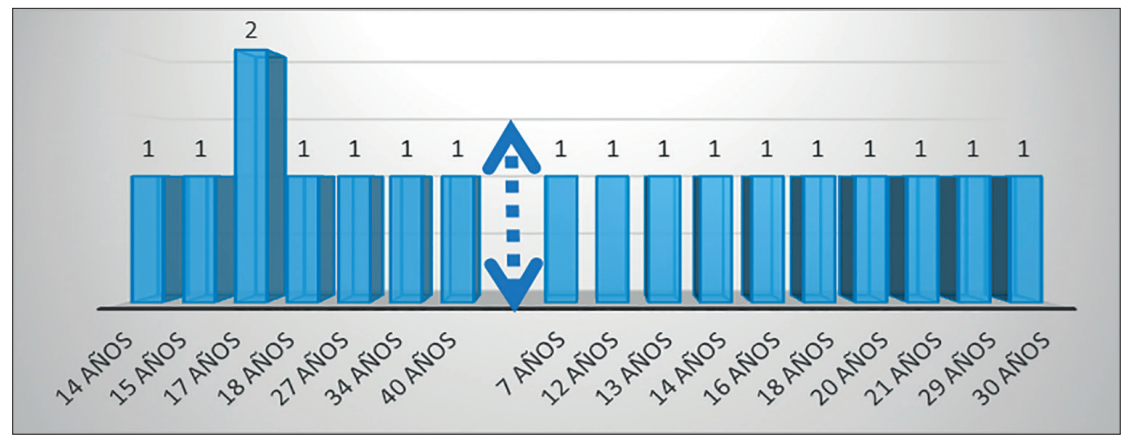

Fuente: Elaboración propia a partir de la jurisprudencia analizada sobre dos y tres delitos de violación 
Por otro lado, en referencia a los sujetos pasivos que han padecido cuatro o más eventos penales, las sentencias condenatorias analizadas muestran unos datos totalmente diferentes a los antes mencionados, ya que existe una amplia mayoría de víctimas dentro de esta tipología delictiva que son menores de edad -72,72\%-, siendo los 11 y 17 años las edades que muestran unos porcentajes superiores al resto.

\section{Gráfico 10. Edad de las víctimas en cuatro o más delitos de violación $(n=33)$}

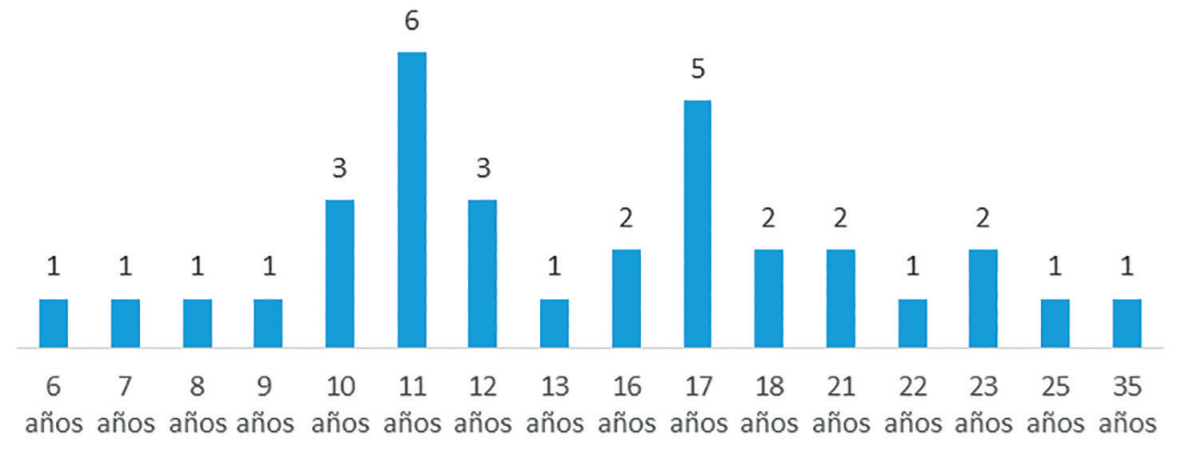

Fuente: Elaboración propia a partir de la jurisprudencia analizada sobre cuatro o más delitos de violación

En referencia a estos últimos datos analizados, el informe sobre delitos contra la libertad e indemnidad sexual de 2018, el cual emite anualmente el Ministerio del Interior, establece que el 29,2\% de las violaciones que se llevaron a cabo durante el mencionado año se produjeron sobre menores de edad, siendo el grupo mayoritario aquel que abarcaba las edades comprendidas entre los 18 y los 30 años $-38,9 \%-35$.

\subsection{Características del delincuente}

A la hora de hacer referencia a las peculiaridades típicas de los sujetos activos, las cuales han sido extraídas de las sentencias condenatorias anteriormente detalladas, resulta de especial interés proceder al análisis de una serie de datos relativos a las particularidades personales, como podrían ser la edad o la nacionalidad de los mismos, así como a los rasgos delictivos de estos individuos, haciendo especial hincapié

35 GOBIERNO DE ESPAÑA (Ministerio del Interior). Informe sobre delitos contra la libertad e indemnidad sexual. 2018. 
en la forma de llevar a cabo el acto; es decir, la actuación en solitario o acompañado por otras personas, los antecedentes penales y los delitos cometidos junto con las mencionadas violaciones.

En referencia al mayor índice de sujetos delincuentes del sexo masculino, teniendo en consideración la teoría criminológica del control social, la cual estableció que «la pregunta que la teoría del poder/control inevitablemente se hace es: cómo y por qué los individuos ubicados en posiciones adolescentes masculinas están más libres para incurrir en desviación ${ }^{36}$.

En un intento por determinar qué sujetos podrían ser catalogados como violadores seriales, Park, Schlesinger, Pinizzotto y Davis afirman que serán aquellas personas que hayan cometido dos o más acciones criminales relacionadas con este tipo delictivo, existiendo un período de tiempo entre dichos acontecimientos punibles ${ }^{37}$.En este sentido, Stevens, en un intento de confeccionar una definición sobre este tipo de criminales, afirma que «la violación es el conocimiento carnal a través del uso de la fuerza o la amenaza de la misma. Cuando ocurre más de una vez por el mismo perpetrador, se llamará violación en serie» ${ }^{38}$.

En consecuencia, la realización de este tipo de acciones lleva aparejada un hilo de incredulidad por parte de la sociedad, la cual se pregunta cómo es posible que se realicen este tipo de actos delictivos. Así, en un intento de aclarar los motivos que llevan a una persona a convertirse en un violador, Martínez Catena y Redondo Illescas afirman que «la perspectiva presentada sugiere que aquellos chicos que viven en su infancia y adolescencia experiencias traumáticas como abandono o desatención familiar, rechazo afectivo, crianza inconsistente o victimización sexual pueden mostrar déficits personales como baja autoestima, problemas de comunicación y relación personal, falta de empatía e hipersexualización. Si ello se combina con la exposición de los sujetos a vivencias sexuales anómalas (contactos sexuales con adultos, con menores, sexo violento, etc.) pueden favorecerse en un joven unas preferencias sexuales desviadas (sexo violento o con niños) y dificultarse en él la adquisición de los imprescindibles controles e inhibidores frente a tales conductas ilícitas» ${ }^{39}$.

36 Hagan, J., "Micro-and macro- structures of delinquency causation and a powercontrol theory of gender and delinquency», en Messner (eds.), Theoretical integration in the study of deviance and crime. Problems and prospects, New York, 1989, pág. 152.

37 Park, J., Schlesinger, L.B., Pinizzotto, A.J., and Davis, E.F., "Serial and singlevictim rapists: differences in crime-scene violence, interpersonal involvement, and criminal sophistication», en Behavioral Sciences \& The Law, vol. 26, 2008, págs. 227-237.

38 STEVENS, D.J., Inside the mind of sexual offenders: predatory rapists, pedophiles, and criminal profiles, New York, 2001, pág. 10.

39 Martínez-Catena, A., y Redondo Illescas, S., «Etiología, prevención y tratamiento de la delincuencia sexual», en Anuario de Psicología Jurídica, vol. 26, 2016, págs. 19-29. 
En este sentido, como se ha detallado anteriormente, una de las principales características que presentan estos individuos es aquella que hace referencia a la falta de empatía. En este sentido, Marshall y Fernández afirman que dichos sujetos «carecen de empatía sólo con sus víctimas y no en general. Es decir, no reconocen el daño que han causado» ${ }^{40}$.

En referencia a los violadores seriales, Garrido Genovés diferencia a aquellos que se muestran como unos psicópatas sexuales de los que no lo son. En este sentido, dicho autor habla sobre la peligrosidad extrema que presentan los primeros, ya que «son muy conscientes de su actividad criminal, planifican con detalle los asaltos y buscan escapar de patrones geográficos definidos que sirvan para que la policía pueda prever con antelación dónde van a cometer la próxima agresión. [...], estos psicópatas son más temibles porque son capaces de vivir una $<<$ doble vida $>>$ con toda naturalidad, sabedores de que esa fachada de empleado, hijo y novio es la mejor mascarada para cubrir su impulso implacable de sentir placer y control en el sufrimiento y la vejación de sus víctimas. Ese control se reflejaba en la víctima elegida, el dominio del tiempo y del lugar donde atacar» ${ }^{41}$.

Por otro lado, haciendo especial hincapié en los mencionados criminales, en una investigación llevada a cabo sobre 572 agresores sexuales adultos, Harris, Knight, Smallbone y Dennison, destacaron que estos delincuentes presentaban una versatilidad delictiva mayor que el resto de sujetos que se encuadraban dentro de dicha tipología penal ${ }^{42}$.

Para proceder al estudio de los violadores seriales, resulta preciso detallar las principales tipologías que versan sobre este tipo de delincuentes. En primer lugar, Groth, Burgess y Holmstrom establecieron tres patrones fundamentales a la hora de hablar de estos criminales, teniendo gran repercusión dentro de la doctrina criminológica. Así, estos autores destacan los siguientes tipos: i) violador de ira, quien utiliza un exceso de fuerza física para controlar a sus víctimas, a las cuales someten a actos sexuales extremadamente degradantes; ii) violador de poder. Se mueven motivados por la necesidad de ejercer un dominio extremo sobre los sujetos pasivos; y iii) violador sádico. Finalmente, estas personas se excitarán por el dolor, sufrimiento y degradación de sus víctimas. Suelen provocar lesiones físicas, pudiendo producir la muerte de la persona que ha sido agredido por estos individuos ${ }^{43}$.

40 Marshall, W.L., y FernándeZ, Y.M.., "Los delincuentes sexuales en la actualidad», en Marshall, W.L (Coord.), Agresores sexuales, Barcelona, 2001, pág. 98.

41 Garrido Genovés, V., Perfiles criminales. Un recorrido por el lado oscuro del ser humano, Barcelona, 2014, pág. 134.

42 Harris, D.A., KNIGHT, R.A., Smallbone, S., and DENNISON, S., "Postrelease specialization and versatility in sexual offenders referred for civil commitment», en Sexual Abuse: a journal of Research and Treatment, vol. 23, 2011, págs. 243-259.

43 Groth, A.n., Burgess, A., and Holmstrom, L., «Rape, power, anger... cit., pág. 1239-1243. 
En referencia a las aportaciones ofrecidas por Groth, Burgess y Holmstrom, y a pesar de haberlas formulado hace varias décadas, autores como Richards, Washburn, Craig, Taheri y Yanisch afirman que siguen siendo las más fiables dentro de las aportadas por la doctrina criminológica a la hora de definir las principales tipologías de violadores seriales, siendo el modelo más reconocido y aceptado en la actualidad ${ }^{44}$.

Circunstancias personales

En primer lugar, proceder al análisis del infractor se considera un elemento fundamental dentro del ámbito criminológico, ya que, por ejemplo, sirve para discriminar aquellas franjas de edad que son más representativas a la hora de ejecutar un acto criminal o, por el contrario, para establecer una línea temporal en la que se incide en este dato para el estudio de las violaciones que se cometen.

\section{a. Edades de los sujetos activos.}

En lo que respecta a la variable relacionada con la edad del delincuente, se presentan grandes diferencias a la hora de hablar sobre los sujetos que han realizado una violación dos, tres o más veces. Así, en el primero de los supuestos mencionados, en el siguiente gráfico se observa cómo serán las personas de 26 años las que más cometen este tipo de infracción. No obstante, considero que lo más destacable dentro de esta tipología delictiva se centrará en los hechos llevados a cabo por un menor y, en el lado opuesto, por dos sujetos que superan los sesenta y cinco años.

\section{Gráfico 11. Edad de los responsables de dos delitos de violación $(n=15)$}

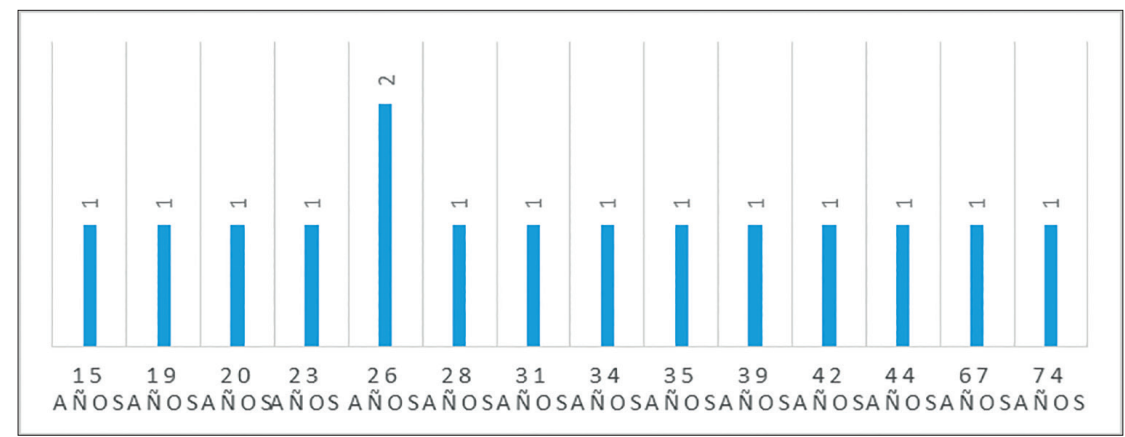

Fuente: Elaboración propia a partir de la jurisprudencia analizada sobre dos delitos de violación

44 Richards, H.J., Washburn, J.J., Craig, R., TAheri, A., and Yanisch, D., «Typing rape offenders from their offense narratives», en Individual Differences Research, vol. 2., 2004, págs. 97-108. 
Por otro lado, en lo referente a los infractores que han cometido tres violaciones, las cifras obtenidas nos detallan la existencia de tres grupos de edades donde existe una mayoría de sujetos agresores. A diferencia del gráfico anterior, en este no existen extremos opuestos, encontrándose todos los individuos analizados entre los 21 y los 36 años.

\section{Gráfico 12. Edad de los responsables de tres delitos de violación $(n=13)$}

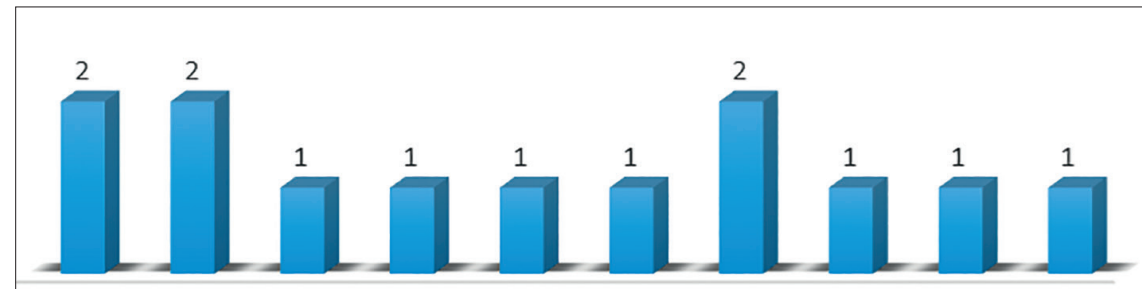

21 años 22 años 23 años 26 años 28 años 31 años 33 años 34 años 35 años 36 años

Fuente: Elaboración propia a partir de la jurisprudencia analizada sobre tres delitos de violación

Finalmente, en los supuestos donde se ha procedido al estudio de aquellas personas que han cometido cuatro o más violaciones, se observa cómo los 18 años será la edad más representativa, estableciéndose una diferencia comparativa en las edades, dado que la franja de 18 se eleva y la correspondiente a los 38, 41 y 43 aparece constituida en la muestra analizada.

\section{Gráfico 13. Edad de los responsables de cuatro o más delitos de violación $(\mathrm{n}=15)$}

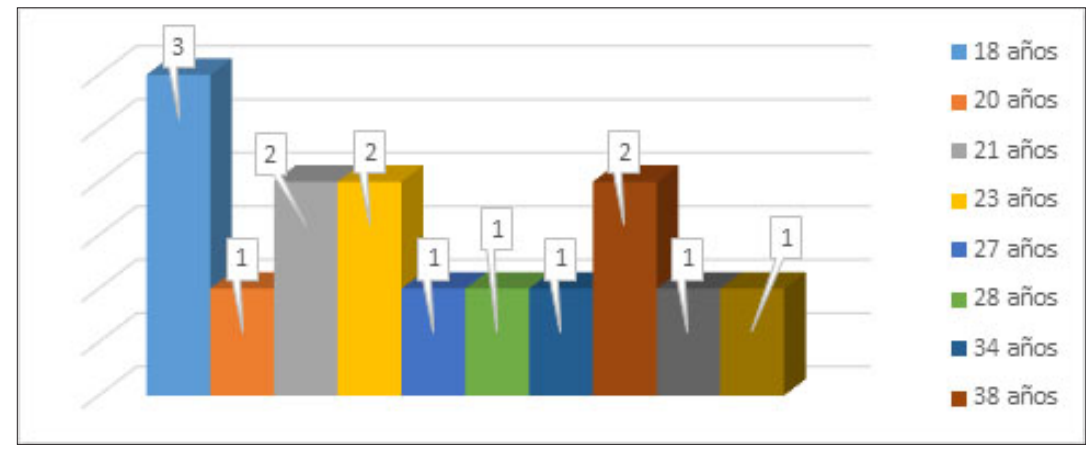

Fuente: Elaboración propia a partir de la jurisprudencia analizada sobre cuatro o más delitos de violación 


\section{b. Nacionalidad de los agresores.}

El estudio de la nacionalidad de los infractores que han cometido algún tipo de acciones delictiva resulta de vital importancia para las investigaciones llevadas a cabo desde una perspectiva criminológica. En cuanto a los hechos analizados a lo largo de este trabajo, en el siguiente gráfico se observa, con independencia del número de violaciones realizadas, cómo la ciudadanía española será la mayoritaria dentro de los violadores seriales. En este sentido, en referencia a las cifras aparecidas en el mismo, existe una gran similitud en torno a los hechos realizados por ciudadanos nacidos en España -en torno las 60\%-, existiendo una clara disimilitud en los porcentajes extraídos para investigar la incidencia de este crimen entre los sujetos que presentan otra procedencia.

\section{Gráfico 14. Nacionalidad de los infractores}

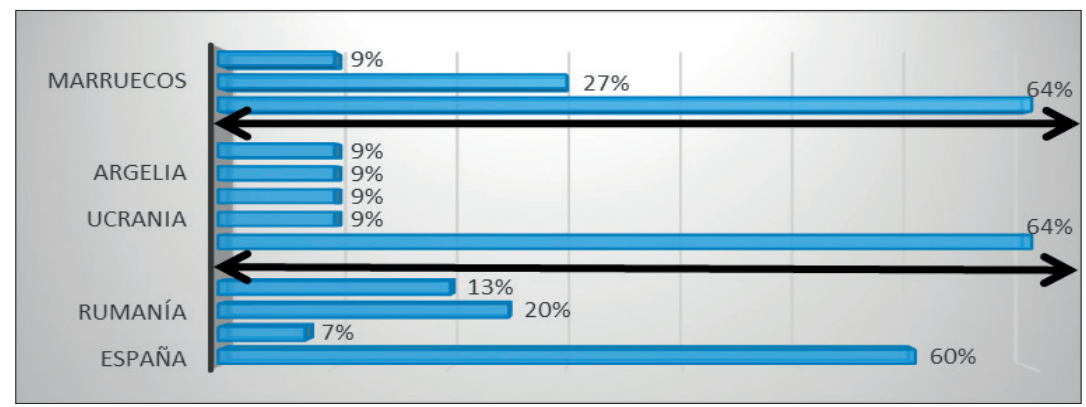

Fuente: Elaboración propia a partir de la jurisprudencia analizada sobre dos, tres, cuatro o más delitos de violación

En el informe sobre delitos contra la libertad e indemnidad sexual, el cual hace referencia a los porcentajes totales referidos a dichas conductas punibles, se aprecian unos datos en los que los criminales de nacionalidad española representan el $87 \%$ de los casos analizados, siendo preciso destacar que los infractores que se encuentran entre los 18 y los 40 años, y que también presentan dicha procedencia, estarán en torno al $60 \%$, coincidiendo estas cifras con las descritas anteriormente para el estudio de los violadores seriales ${ }^{45}$.

\section{Contextos delictivos}

Una vez detalladas las principales peculiaridades personales que definen a estos agresores, el estudio de las características penales y criminológicas que se aglutinan en los sujetos analizados pueden aportar una

45 Gobierno De España (Ministerio del Interior). Informe sobre delitos.......cit., 2018. 
información idónea para la creación de un perfil que genere un beneficio a la hora de establecer potenciales planes de prevención ante los posibles ataques de este tipo de delincuente.

En consecuencia, en lo que respecta a la siguiente variable, sin necesidad de adentrarnos en el delito de violación, resulta de gran relevancia el estudio de las distintas infracciones penales que realizan estos sujetos, las cuales pueden ser realizadas dentro del mismo escenario criminal, pudiendo conseguir una información primordial para señalar las principales motivaciones que llevaron a dichos individuos a realizar tales acciones violentas. En relación con esto, también conviene destacar que los hechos cometidos, generalmente, suelen ser realizados mediante el uso de la fuerza o la intimidación.

\section{a. Infracciones penales realizadas.}

En el estudio de los violadores seriales que cometen dos acciones delictivas, existe una variedad de delitos en los que el uso de la fuerza es habitual, destacando las lesiones y el robo. Así, en el siguiente gráfico se observan diferentes tipologías delictivas, las cuales se podrían subdividir dependiendo de su representatividad, destacando, por otro lado, aquellas que tienen una escasa representatividad dentro del citado análisis, como la trata de seres humanos y el aborto.

\section{Gráfico 15. Otros delitos cometidos por los responsables de dos delitos de violación $(\mathrm{n}=17)$}

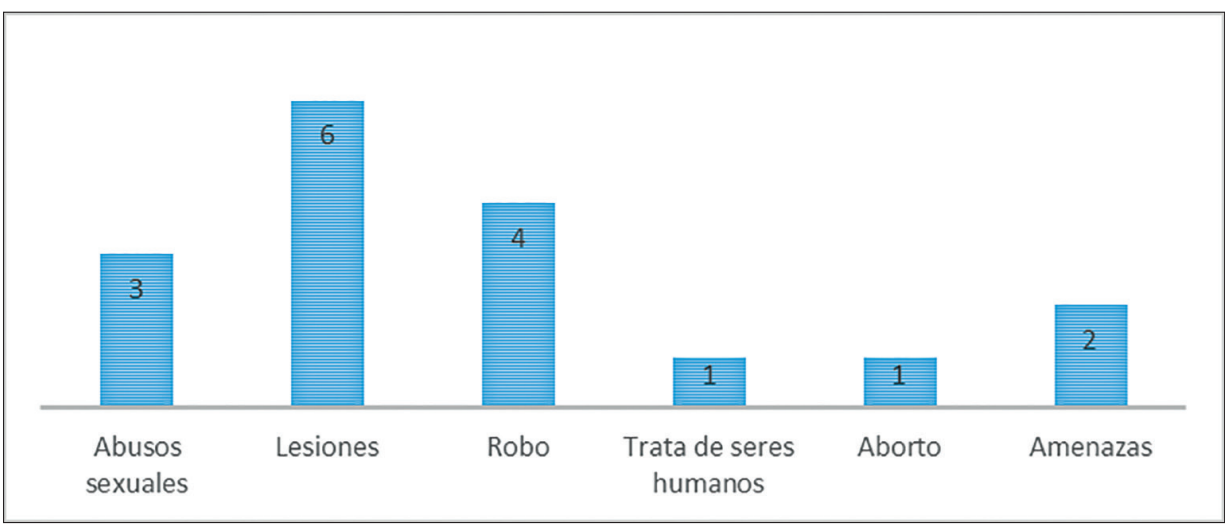

Fuente: Elaboración propia a partir de la jurisprudencia analizada sobre dos delitos de violación

Posteriormente, el análisis de aquellos sujetos que han cometido tres violaciones nos proporciona unos datos diferentes a los antes mencionados, ya que, salvo el robo y las amenazas, el resto de infracciones son disímiles. No obstante, conviene destacar que, a pesar de existir un número 
significativamente menor al expuesto en el gráfico anterior, en el estudio de estos individuos se aprecia la perpetración de un asesinato, por lo que se podría afirmar que la peligrosidad de estas personas es superior.

Gráfico 16. Otros delitos cometidos por los responsables de tres delitos de violación $(n=8)$

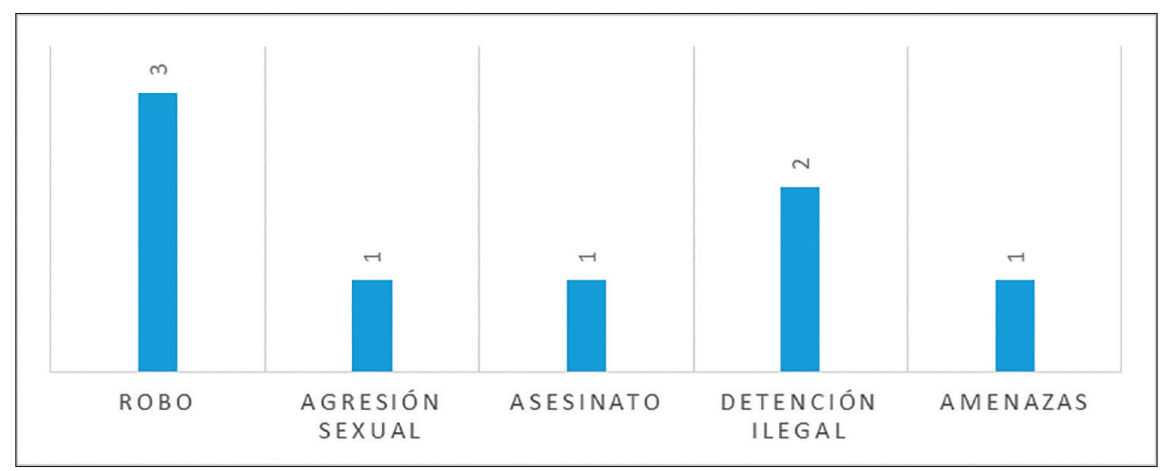

Fuente: Elaboración propia a partir de la jurisprudencia analizada sobre tres delitos de violación

Finalmente, en referencia a los sujetos que han cometido cuatro o más violaciones, existe una mayor variedad de acciones delictivas, pudiendo apreciar cómo el robo se posiciona nuevamente en primer lugar. Por otro lado, cabe destacar el surgimiento de nuevas infracciones (delito de daños, contra la integridad moral, el hurto, contra la administración de justicia y la corrupción de menores), las cuales no habían figurado en los gráficos previos.

\section{Gráfico 17. Otros delitos cometidos por los responsables de cuatro o más delitos de violación $(n=25)$}

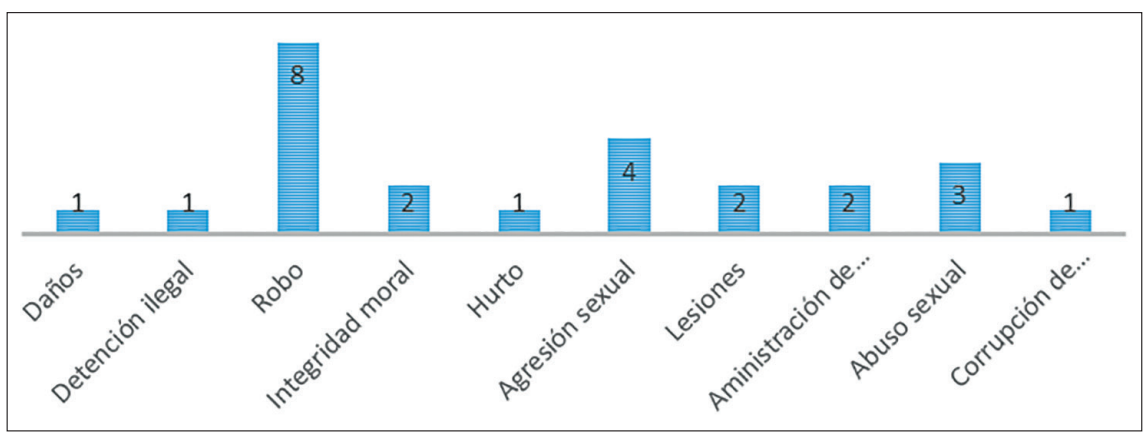

Fuente: Elaboración propia a partir de la jurisprudencia analizada sobre cuatro o más delitos de violación 
En términos genéricos, englobando toda la información obtenida, es decir, dejando de lado las violaciones realizadas, el resultado del análisis de los hechos delictivos cometidos por los violadores seriales, teniendo en cuenta la tipificación mostrada en el Código Penal, se podría categorizar en atención a la representatividad de los mismos dentro de la totalidad de los supuestos estudiados:

a. Mayor representatividad. Los delitos cometidos contra el patrimonio y el orden socioeconómico simbolizan el 34\% de los delitos cometidos por estos delincuentes. Por otro lado, la infracciones que atentan contra la libertad e indemnidad sexual encarnan el $24 \%$, por lo que se podría afirmar que son estos dos tipos delictivos los más realizados por los violadores seriales, sumando entre las dos más del 50\% de las acciones ejecutadas.

b. Representatividad media. Dentro de este grupo de infracciones cabe destacar la presencia de los delitos de lesiones (16\%) y de los realizados contra la libertad (12\%), donde destacarían las detenciones ilegales y las amenazas.

c. Escasa representatividad. Finalmente, en el último nivel, se aglutinan una serie de infracciones penales que presentan una exigua relevancia dentro de la totalidad de los crímenes cometidos, dejando de lado la gravedad y peligrosidad de los mismos. Así, los delitos contra la administración de justicia (4\%), los de tortura y otros delitos contra la integridad moral $(4 \%)$, los de trata de seres humanos $(2 \%)$, de aborto $(2 \%)$ y el homicidio y sus formas (2\%), suman el 14\% de todas las acciones realizadas por los violadores seriales.

\section{b. Antecedentes penales.}

En referencia a dicha variable, Jacobs y Larrauri Pijoan establecen que, en base a la posible reinserción social, el ostentar antecedentes penales lleva aparejada una doble dificultad para las personas afectadas ya que, por un lado, comportan una gran problemática a la hora de intentar conseguir un futuro puesto de trabajo; mientras que, por otro, suponen el «estigma perpetuo de delincuente» ${ }^{46}$.

Dentro de este mismo hilo argumental, Larrauri Pijoan, además de incidir en la necesidad de llevar a cabo más estudios relacionados con esta temática, afirma que «existe la creencia generalizada de que poseer antecedentes penales puede comportar importantes consecuencias para el futuro laboral de la persona y para el ejercicio de sus derechos» ${ }^{47}$.

46 Jacobs, J.B., y LARrauri PiJOAN, E., «¿Son las sentencias públicas? ¿Son los antecedentes penales privados? Una comparación de la cultura jurídica de Estados Unidos y España», en InDret. Revista para el análisis del derecho, vol. 4, 2010, págs. 1-52.

47 Larrauri PiJOAn, E., "Antecedentes penales», en Eunomía. Revista en Cultura de la Legalidad, Vol. 8, 2015, págs. 153-159. 
En este sentido, se podría afirmar que los antecedentes penales se conciben como unas herramientas jurídicas que nos narran acontecimientos delictivos pasados, así como un enlace directo al presentismo, que nos sitúa en un momento clave para valorar el trascurso de la historia del infractor y el devenir de posibles acciones punibles futuras y, por ende, del desenvolvimiento vital del sujeto.

En atención a las sentencias analizadas, resulta relevante destacar que, en contra de lo que podría parecer más habitual entre la gran parte de la sociedad a la hora de hablar sobre estos criminales, existe una amplia mayoría de violadores seriales que no presentan antecedentes penales.

\section{Gráfico 18. Antecedentes penales de los violadores seriales}

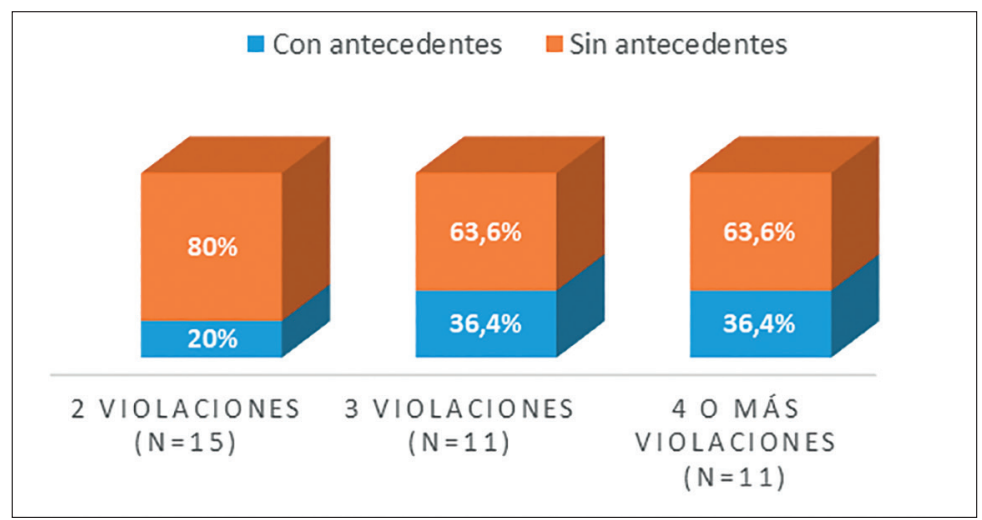

Fuente: Elaboración propia a partir de la jurisprudencia analizada sobre dos, tres, cuatro o más delitos de violación

En referencia a la afirmación realizada tras la exposición de los datos obtenidos en las sentencias condenatorias, desde una perspectiva criminológica se podría afirmar que la carencia de antecedentes delictivos en los violadores seriales no resulta del todo llamativa, debido a que este tipo de infractores no suelen presentar una amplia versatilidad criminal primaria, ya que su fantasía radica exclusivamente en llevar a cabo una serie de actos de naturaleza sexual. No obstante, cabe destacar que la comisión de dichas acciones sí pueden servir como un acontecimiento previo a la realización de otras conductas punibles, como podría ser el caso de los asesinos en serie, quienes suelen presentar antecedentes penales relacionados con este tipo de agresión sexual ${ }^{48}$.

48 Pintado Alcázar, A., Análisis criminológico de los asesinos en serie, Madrid, 2017, pág. 411. 


\section{c. Formas de ejecución.}

Los crímenes pueden ser cometidos siguiendo diferentes procedimientos, pudiendo ser llevados a cabos de formas individual o mediante la colaboración de otras personas, ya sean dos, tres o, incluso, más sujetos. En este sentido, el Código Penal nos muestra una diversidad de terminologías jurídicas para catalogar a estos individuos. Así, el artículo 570 ter establece que concurrirá la existencia de un grupo criminal cuando se produzca «la unión de más de dos personas que, [...], tengan por finalidad o por objeto la perpetración concertada de delitos».

Previamente, el artículo 28 de dicho texto legal hace referencia a la coautoría, estableciendo que serán considerados autores aquellos sujetos que realizan el acto "por sí solos, conjuntamente o por medio de otro del que se sirven como instrumento», haciendo especial hincapié en la figura de los inductores y de los cooperadores necesarios. En referencia a dicha definición, atendiendo a la expresión «conjuntamente», se podría tener en consideración la creación de una corporación criminal, también denominada "Societas scaeleris», en la que los participantes en la acción delictiva habrán llevado a cabo una serie de reuniones previas en las que se pondrán en común aquellas actuaciones punibles que se quieren realizar, estableciéndose una especie de escalafones, atendiendo a la mayor gravedad e intensidad de las infracciones ejecutadas.

En atención a los datos extraídos de las diferentes sentencias analizadas, tal y como se recoge en el siguiente gráfico, los sujetos estudiados presentan discrepancias a la hora de ejecutar sus acciones delictivas, ya que, dependiendo del número de violaciones cometidas, llevarán a cabo las diferentes actuaciones de forma individual o valiéndose de otros sujetos para poder consumar sus fantasías criminales.

\section{Gráfico 19. Formas de actuación de los violadores seriales}

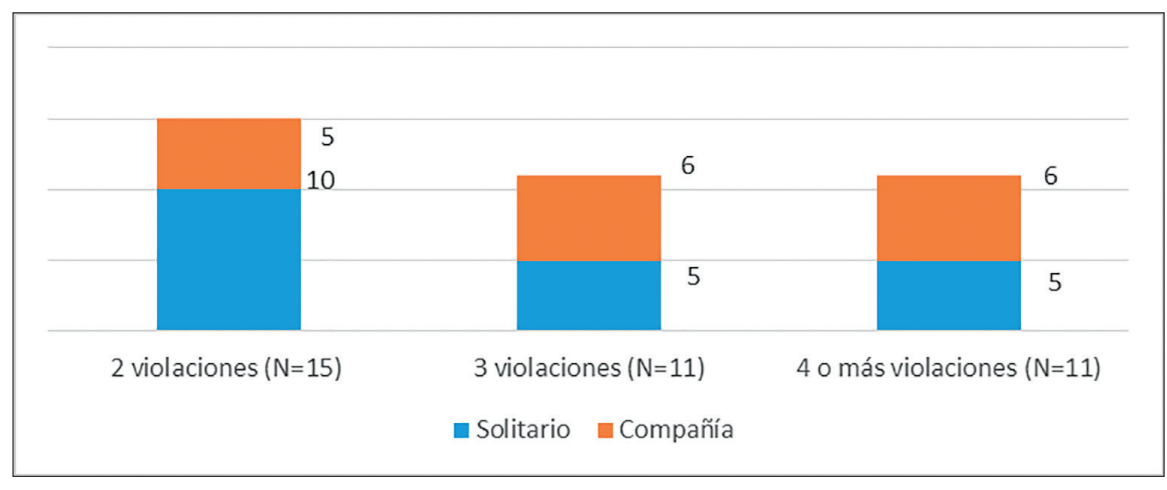

Fuente: Elaboración propia a partir de la jurisprudencia analizada sobre dos, tres, cuatro o más delitos de violación 
Como ha podido comprobarse en el gráfico anterior, los sujetos que cometen dos violaciones suelen actuar en solitario, presentando un $66,66 \%$ de los casos analizados. En el lado opuesto se encontrarían aquellos individuos que han incurrido en tres o más acciones delictivas, ya que se aprecia cómo suelen realizar sus actos punibles acompañados por otras personas. Así, tras el análisis de todas las cifras aquí presentadas, el concurso de delincuentes mostraría unos datos levemente superiores $(54,54 \%)$ a los expuestos para la consumación de forma individual $(45,46 \%)$.

\subsection{Creación de un perfil criminológico}

La realización de los perfiles criminales resulta transcendental a la hora de intentar unificar criterios para la identificación de diferentes delincuentes. Canter y Heritage, tras el estudio de 27 violadores, y a raíz de los resultados obtenidos, establecieron cinco elementos determinantes relacionados con el comportamiento de estos individuos, es decir, crearon un perfil criminológico en base a sus características conductuales. Así, los diferentes grupos que crearon dichos autores pueden establecerse en la siguiente clasificación: i) sexualidad; ii) agresividad; iii) impersonalidad de las acciones; iv) criminalidad; y, por último, v) intimidad ${ }^{49}$.

En atención a los datos analizados a lo largo de la investigación realizada, se han extraído una serie de variables que caracterizan a los violadores seriales que actúan dentro del territorio nacional. En este sentido, cabe señalar que dicha información se ha generado aglutinando los resultados obtenidos en los diferentes sujetos estudiados.

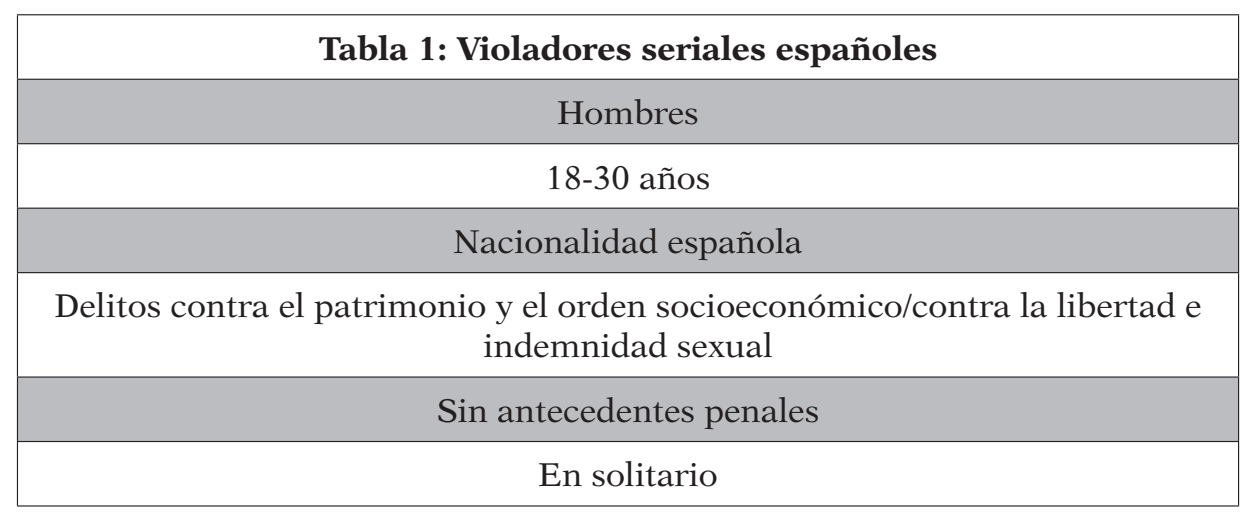

49 CANTER, D., and Heritage, R., "A multivariate model of sexual offence behaviour: developments in «offender profiling» I», en The Journal of Forensic Psychiatry, vol.1., 1990, págs. 185-212. 
Como se puede apreciar en la tabla anterior, tras la extrapolación de los datos obtenidos de los diferentes sujetos analizados, se han detectado seis patrones identificativos de estos criminales, los cuales hacen referencia a determinadas características personales y delictivas. No obstante, conviene detallar cada una de ellas para poder esclarecer los motivos esenciales que hacen que dichas personas presenten dichos rasgos identitarios.

I. Sexo. La totalidad de las sentencias analizadas hacen referencia a los varones como sujetos activos de este tipo delictivo. En este sentido, el informe sobre delitos contra la libertad e indemnidad sexual elaborado anualmente por el Ministerio del Interior establece unos porcentajes muy superiores en los infractores de género masculino sobre los del femenino, estableciéndose para estas últimas unos datos del 0,47\% en el año $2017^{50}$ y del 1,39\% en $2018^{51}$.

II. Los datos aquí mencionados podrían identificarse con los expuestos por instituciones penitenciarias para hacer referencia al número de internos de ambos sexos a nivel nacional, donde se aprecia cómo los hombres son más propensos a cometer determinadas acciones delictivas, existiendo un 92,53\% de infractores varones y un $7,47 \%$ de mujeres ${ }^{52}$.

III. Edad. Las sentencias analizadas nos muestran cómo la gran mayoría de estos delitos son cometidos por personas con edades comprendidas entre los 18 y los 30 años. En este sentido, el estudio de la correlación existente entre esta variable y la delincuencia resulta de vital importancia para la criminología, ya que aporta información concluyente a la hora de llevar a cabo determinadas pesquisas. Así, en consecuencia, Birkbeck afirma que «el criminólogo podría dar a la edad un lugar de gran importancia en sus investigaciones ${ }^{53}$.

IV. Nacionalidad. En referencia a esta variable, Morillas Fernández establece que representa «una trascendental importancia en las sociedades contemporáneas para entender el fenómeno delincuencial» ${ }^{54}$. En este sentido, las sentencias analizadas exteriorizan que los infractores españoles son más propensos a cometer este tipo de acción delictiva. No obstante, cabe destacar

50 Gobierno De España (Ministerio del Interior). Informe sobre delitos contra la libertad e indemnidad sexual. 2017.

51 GobIERno De EsPaÑa (Ministerio del Interior). Informe sobre delitos.......cit., 2018.

52 Recurso electrónico disponible en: http://www.institucionpenitenciaria.es/.

53 BIRKBECK, C.H., "El significado de la adolescencia para la criminología», en Buenos Arús, F., y Guzmán Dalbora, J.L. (Eds.), Derecho penal y criminología como fundamento de la política criminal: estudios en homenaje al profesor Alfonso Serrano Gómez, Madrid, 2006, pág. 168.

54 Morillas Fernández, D.L., "Análisis de las principales variables de la delincuencia juvenil en España», en Revista de derecho, empresa y sociedad, vol.3, 2013, pág. 208. 
la elevada cifra de internos extranjeros existentes en nuestro país, ya que, según establece la Secretaría General de Instituciones Penitenciarias, con fecha de 29 de febrero de 2020, el número de reclusos foráneos mostraba un porcentaje del $28,13 \%$ del total de la población encarcelada ${ }^{55}$.

V. Tipo delictivo cometido. Como ya se ha podido observar a lo largo del análisis jurisprudencial realizado, los sujetos que se pueden catalogar como violadores en serie suelen realizar sus acciones acompañadas por otro tipo de eventos delictivos, los cuales suelen enmarcarse dentro de los delitos cometidos contra el patrimonio y el orden socioeconómico y de los realizados contra la libertad e indemnidad sexual. Esta correlación podría deberse a la vulnerabilidad de las víctimas en el momento de llevar a cabo el delincuente su acto principal, es decir, la violación del sujeto pasivo.

VI. Sin antecedentes penales. Ante la gravedad de los hechos cometidos, podría resultar anómala la carencia de este tipo de variable. No obstante, el estudio realizado se basa en diferentes sentencias condenatorias, las cuales especifican la ausencia de los mismos en estos delincuentes.

VII.Forma de actuar. Los casos analizados muestran acciones delictivas realizadas en su mayoría en solitario, es decir, estos delincuentes no se sirven de la ayuda y colaboración de otros individuos para llevar a cabo tales acontecimientos punibles. No obstante, cabe destacar que aquellos supuestos en los que se hayan cometido tres o más violaciones sí suele ser más habitual que los agresores realicen este tipo de infracciones valiéndose de la compañía de otras personas.

\section{Conclusiones}

Tras la realización del análisis llevado a cabo sobre las investigaciones desarrolladas por la doctrina jurídica y criminológica, así como sobre las diferentes sentencias condenatorias seleccionadas, cabe destacar que los resultados obtenidos arrojan una serie de hipótesis referidas a los violadores en serie que actúan dentro del territorio nacional. Así, las principales conclusiones alusivas a estos delincuentes pueden resumirse en las siguientes:

$1^{\mathrm{a}}$. Tomando como referencia el número total de acciones delictivas referidas a este tipo de infracciones, se configura como necesaria una respuesta penal eficaz por parte de la justicia, ya que se estiman que

55 Recurso electrónico disponible en: http://www.institucionpenitenciaria.es/. 
son delitos que generan en la víctima un dolor extremo, ya sea físico o psicológico. Así, cuando se producen agresiones contra la indemnidad o libertad sexual, además de la mencionada intervención por parte de los órganos judiciales, se hacen necesarios estudios desde una perspectiva psicológica y criminológica para aclarar qué acontecimientos psicosociales han acontecido a lo largo de la vida de estos sujetos.

$2^{\text {a }}$. La sociedad siente aversión por aquellas personas que son capaces de cometer un acto delictivo de estas características. Resulta habitual pensar que dicha hostilidad va en aumento si las víctimas son menores de edad, dato que puede ser considerado como una constante dentro del citado contexto criminal. Por otro lado, en referencia al agresor, existen una serie de peculiaridades que lo identifican y lo estigmatizan como una persona insensible, violenta, cruel o, incluso, psicópata.

$3^{\text {a }}$. En lo que respecta a la edad de las víctimas, resulta destacable mencionar que las mismas se configuran en dos grupos claramente diferenciados; las mayores y las menores de edad, siendo estas últimas las que presentan mayores porcentajes entre los sujetos pasivos de los violadores seriales que han actuado en España. No obstante, cabe señalar que muchas de las que son adultas, tienen edades próximas a los 18 años, hecho que se podría configurar como concluyente a la hora de remarcar como un acontecimiento determinante el ser consideradas como personas más vulnerables que el resto.

$4^{\text {a }}$. La configuración de las mujeres como sujetos activos del delito de violación se presenta como un acontecimiento poco habitual, siendo en su amplia mayoría individuos de sexo masculino los que cometen este tipo de acciones delictivas. No obstante, ante la posible existencia de féminas entre los agresores de este tipo punible, el estudio de la conducta criminal de las mismas puede aportar una información que atesore gran importancia.

$5^{\text {a }}$. Tras el análisis de las diferentes sentencias, se podría afirmar que existe una importancia relevante a la hora de establecer el nivel de parentesco entre agresor y víctima. Este condicionante influirá consistentemente en el acto criminal, así como en la forma de actuación del mismo, siendo más propensa la realización en solitario cuando existe una relación previa entre ambos. Por otro lado, en el caso de tratarse de personas desconocidas, la tendencia a la hora de actuar delictivamente puede ser individual o colectiva, destacando una probabilidad mayor actualmente en la realización de estos hechos de forma agrupada.

$6^{\mathrm{a}}$. Desde un punto de vista criminológico, la creación de perfiles criminales es de vital importancia, ya que proporcionará información relevante sobre determinados grupos de delincuentes, intentando con ello crear un flujo de información veraz, tanto para las autoridades competentes en la investigación de determinadas acciones delictivas como para otros científicos que decidan hacer uso de dichos estudios. 
$7^{\mathrm{a}}$. Finalmente, en orden a los datos extraídos en este estudio, se puede afirmar que los violadores seriales son aquellas personas que, actuando de forma individual o conjuntamente, cometen dos o más violaciones, las cuales pueden presentarse ante la misma o diferente víctima, pudiendo existir un período determinado de tiempo entre las diversas acciones.

\section{Bibliografía}

Asua Batarrita, A., «Las agresiones sexuales en el nuevo Código Penal: Imágenes culturales y discurso jurídico», en Análisis del Código Penal desde la perspectiva de género, Vitoria - Gazteiz, 1998.

Barbaree, H. E., and Langton, C. M., «The effects of child sexual abuse and family environment», en Barbaree and Marshall (Eds.), The juvenile sex offender, New York, 2006.

BIRKBECK, C.h., «El significado de la adolescencia para la criminología», en Buenos Arús, F., y Guzmán Dalbora, J.L. (Eds.), Derecho penal y criminología como fundamento de la política criminal: estudios en homenaje al profesor Alfonso Serrano Gómez, Madrid, 2006.

Cano Cuenca, A., «Tratamiento práctico de los delitos contra la libertad sexual. Especial referencia a los abusos sexuales a menores», en Roig Torres (Dir.), Tratamiento Penal de la delincuencia sexual. Comparativa entre los sistemas norteamericano y europeo, Valencia, 2014.

CANTER, D., and Heritage, R., "A multivariate model of sexual offence behaviour: developments in "offender profiling» I», en The Journal of Forensic Psychiatry, vol.1., 1990.

Echeburúa Odriozola, E., y De Corral Gargallo, P., «Secuelas emocionales en víctimas de abuso sexual en la infancia», en Cuadernos de Medicina Forense, Vol. 12, 2006.

Ferrer PéreZ, V.A., Y Bosch Fiol, E., «La percepción del acoso sexual en el ámbito universitario», en Revista de Psicología Social, Vol. 29, 2014.

GaRAPON, A., Juez y Democracia, Barcelona, 1997.

GarRido Genovés, V., Perfiles criminales. Un recorrido por el lado oscuro del ser humano, Barcelona, 2014.

Groth, A. N., Burgess, W., and Holmstrom, L. L., «Rape: Power, anger and sexuality», en American Journal of Psychiatry, vol. 134, 1977.

HAGAN, J., «Micro-and macro- structures of delinquency causation and a power-control theory of gender and delinquency», en Messner (eds.), Theoretical integration in the study of deviance and crime. Problems and prospects, New York, 1989.

HarRis, D.A., KNight, R.A., S Mallbone, S., and Dennison, S., «Postrelease specialization and versatility in sexual offendersrefarredfor civil 
commitment», en Sexual Abuse: a journal of Research and Treatment, vol. 23, 2011.

Hendriks, J., and BiJleveld, C. C., «Juvenile sexual delinquents: contrasting child abusers with peer abusers», en Criminal Behaviour and mental health, vol. 14, 2004.

JACobS, J.B., y LARRAuri PiJOAN, E., «¿Son las sentencias públicas? ¿Son los antecedentes penales privados? Una comparación de la cultura jurídica de Estados Unidos y España», en InDret. Revista para el análisis del derecho, vol. 4, 2010.

LAMARCA PÉrez, C., «Delitos contra la libertad e indemnidad sexuales», en Lamarca Pérez (Coord.), Delitos. La parte especia del Derecho Penal, Madrid, 2018.

Larrauri Pijoan, E., «Antecedentes penales», en Eunomía. Revista en Cultura de la Legalidad, Vol. 8, 2015.

LARRAURi PiJOAN, E., Introducción a la criminología y sistema penal, Madrid, 2018.

Marshall, W.1., y Fernández, Y.M.., «Los delincuentes sexuales en la actualidad», en Marshall, W.L (Coord.), Agresores sexuales, Barcelona, 2001.

Martínez-Catena, A., y Redondo Illescas, S., «Etiología, prevención y tratamiento de la delincuencia sexual», en Anuario de Psicología Jurídica, vol. 26, 2016.

Mckibbin, W.F., Shackelford, T., Goetz, A.t., and Starrarr, V.G., «Why do men rape? An evolutionary psychological perspective», en Review of General Psychology, Vol. 12, 2008.

Morales Prats, F., y García Albero, R., «De las agresiones sexuales», en Quintero Olivares (Dir.), Comentarios al Código Penal Español, Pamplona, 2016.

Morillas Fernández, D.L., Análisis dogmático y criminológico de los delitos de pornografía infantil. Especial consideración de las modalidades comisivas relacionadas con Internet, Madrid, 2005.

Morillas Fernández, D.L., "Análisis de las principales variables de la delincuencia juvenil en España», en Revista de derecho, empresa y sociedad, vol.3, 2013.

Morillas Fernández, D.L., "Los delitos contra la libertad e indemnidad sexuales», en Morillas Cueva (Dir.), Estudios sobre el Código Penal reformado. (Leyes Orgánicas 1/2015 y 2/2015), Madrid, 2015.

Muñoz Conde, F., Derecho penal: parte especial, Valencia, 2019.

Muñoz Conde, F., y García Arán, M., Derecho Penal. Parte General, Barcelona, 2015. 
ORTS BerEnguer, E., "Delitos contra la libertad e indemnidad sexuales (y III): Exhibicionismo y provocación sexual. Prostitución, explotación sexual y corrupción», en Derecho Penal. Parte Especial, Valencia, 2019.

Park, J., Schlesinger, L.B., Pinizzotto, A.J., and Davis, E.F., «Serial and single-victim rapists: differences in crime-scene violence, interpersonal involvement, and criminal sophistication», en Behavioral Sciences \& The Law, vol. 26, 2008.

PÉrez Alonso, E., «Concepto de abuso sexual: contenido y límite mínimo del delito de abusos sexuales», en InDret. Revista para el Análisis del Derecho, 3/2019, 2019.

Pintado Alcázar, A., Análisis criminológico de los asesinos en serie, Madrid, 2017.

Redondo Illescas, S., y Andrés Pueyo, A., «La psicología de la delincuencia», en Papeles del psicólogo, vol. 28, 2007.

Redondo Illescas, S., y Garrido Genovés, V., Principios de criminología, Valencia, 2013.

Richards, H.J., Washburn, J.J., Craig, R., TAheri, A., and Yanisch, D., "Typing rape offenders from their offense narratives», en Individual Differences Research, vol. 2., 2004.

Ropero CARRASCO, J., «Reformas penales y política criminal en la protección de la indemnidad sexual de los menores. El proyecto de 2013», en Estudios Penales y Criminológicos, Vol. XXXIV, 2014.

SÁInZ-Cantero Caparrós, J.E., "De los delitos contra la libertad e indemnidad sexuales (I)», en Morillas Cueva (Coord.), Sistema de Derecho Penal Español. Parte Especial, Madrid, 2011.

Serrano Gómez, A., y Serrano Maíllo, A., "Delitos contra la libertad e indemnidad sexual (II)», en Curso de Derecho Penal. Parte Especial, Madrid, 2019.

Serrano Maíllo, A., El problema de las contingencias en la teoría del autocontrol. Un test de la teoría general del delito, Madrid, 2013.

STEVEns, D.J., Inside the mind of sexual offenders: predatory rapists, pedophiles, and criminal profiles, New York, 2001.

Turvey, B.E., Criminal profiling. An introduction to behavioral evidence analysis, New York, 2014.

Waterhouse, G.F., Reynolds, A., and Egan, V., «Myths and legends: The reality of rape offences reported to a UK police force», en The European Journal of Psychology Applied to Legal Context, vol. 8, 2016.

Wikström, P.H., «Por qué se delinque: Una teoría de la acción situacional», en Revista de derecho penal y criminología, vol.17, 2017. 